\title{
A DISPUTA PELO DIREITO AO ESPAÇO NO RIO DE JANEIRO: EMBATES ENTRE NECROPOLIITICA NEOLIBERAL E MOVIMENTOS DE RESISTÊNCIA
}

\author{
THE DISPUTE FOR THE RIGHT TO THE SPACE IN RIO DE JANEIRO: CONFRONTATION \\ BETWEEN NEOLIBERAL NECROPOLITICS AND RESISTANCE MOVEMENTS
}

Daniel Marcos MARTINS ${ }^{1}$

Artigo recebido em 11/09/2019, aceito em 02/04/2020, publicado em 28/07/2020.

Palavras-chave:

Espaço urbano,

Mentalidades,

Necropolítica,

Estado neoliberal,

Poder

Keywords:

Urban space,

Mentalities,

Necropolitics,

Neoliberal state,

Power

\section{RESU M O}

Este artigo busca analisar a apropriação neoliberal da cidade do Rio de Janeiro, sua transformação e mercantilização, assim como, a reação de movimentos contrários que ocupam e ressignificam o mesmo espaço. Os movimentos de resistência confrontam a lógica neoliberal, reivindicando seu direito à cidade. Esse artigo também analisa as relações de poder e o controle político sobre a vida, assim como a reflexão sobre novas alternativas que possam fugir da lógica imposta pelo Estado neoliberal.

\footnotetext{
A B S T R A C T

This article aims to analyze the neoliberal appropriation of the city of Rio de Janeiro, its transformation, and mercantilization, as well as the opposition movements' reaction who occupy and resignify the same space. The resistance movements confront the neoliberal logic, claiming their right to the city. This article also analyzes the power relations and political control over life, as well as the reflection on new alternatives that can escape from the logic imposed by the neoliberal State.
}

${ }^{1}$ Historiador, Mestre em Música e Professor na Escola Técnica do Rio de Janeiro (ETERJ) e nas Faculdades Integradas Campo-Grandenses (FIC). E-mail: danielmmartinscontato@gmail.com 


\section{INTRODUÇÃO}

- Porque o pai dele era Raimundo e morreu foi aqui mesmo lutando pela gente, pelo direito da gente. Era um homem e tanto. Valia dez destes que a gente encontra por aí.

-Meu pai? - fez Pedro Bala, que daquelas histórias só conhecia vagos rumores.

- Teu pai, era. A gente chamava ele de Loiro. Quando foi da greve fazia discurso pra gente, nem parecia um estivador. Foi pegado por uma bala.

(Capitães da Areia - Jorge Amado)

Esse artigo é compreendido dentro de uma conjuntura: a reorganização do espaço urbano pela lógica neoliberal e as reações à ocupação do espaço urbano com os protestos. Essa narrativa será discutida a partir de níveis de duração, como propostos por Bittencourt (2008) que serão 3: 1) 0 primeiro nível, os acontecimentos; a cidade, quem assume o governo, suas intenções, quais empresários fazem acordos com 0 Estado; 2) o segundo, conjunturas da relação de poder, demonstrada nesta investigação pela implantação do plano neoliberal de transformação da cidade, a naturalização da necropolítica e 3) o terceiro nível, os movimentos de reação contra tais ocupações. Também, demonstraremos nesse último nível o debate sobre os comportamentos coletivos enraizados na crença ideológica neoliberal que se articula com a história das mentalidades, apresentado através da mudança de percepção da população e seu convencimento de que a nova estrutura proposta é justificável.

Portanto, esse artigo aborda a duração de nível dois e três, tomando como realidade o primeiro nível, considerando a atual presidência de 2019, com Jair Bolsonaro e no contexto do Rio de Janeiro com o Prefeito Marcelo Crivella (2017-2020), Eduardo Paes (2009-2013 e 2013 - 2017) e o Governador Wilson Witzel (20192022). Por história da mentalidade compreendo com o enfoque ao mundo mental, modos de sentir, representações coletivas e o inconsciente coletivo aqui demonstrado através da análise do senso comum e convencimento da população acerca do projeto neoliberal para a cidade (BARROS, 2004, p.39). Buscando analisar a dimensão mental através do convívio e uso do espaço urbano a fim de demonstrar as atitudes coletivas "[...] ou de padrões de sensibilidade". (BARROS, 2004, p.41).

Esse artigo toma como base a percepção de uma cidade hostil e segregacionista, com o emprego da ideia de uma "política de morte", que fomenta a separação e nega recursos aos hospitais, escolas etc. ao que compreendemos como "necropolítica neoliberal", termo desenvolvido por Clara Valverde Gefaell (2015), tomado de empréstimo o conceito de necropolítica, do historiador Achille Mbembe. Argumento que existe um projeto neoliberal de modificação da cidade, bem como a existência da "necropolítica neoliberal", presente na 
política de extermínio, de descaso com a saúde, educação, com os espaços periféricos onde se concentram comunidades pobres. Em outras palavras: a prática violenta é uma das ações mais usadas no processo de implantação do neoliberalismo, utilizando a violência simbólica, psicológica e física.

Vale ressaltar previamente que compreendo os grupos que serão citados sob a ótica de Latour (2012), na qual, a concepção tradicional de grupos não existe, mas sim, a formação de grupos e suas performances. Rastreando as pistas deixadas pelas suas atividades, demonstrando que esses são agrupados e reagrupados, formados principalmente por sujeitos e atores sociais que fazem dessas reuniões, encontros maleáveis sem estrutura rígida. Não existe inércia, embora para alguns grupos temporários seja desejada, como aqueles que detêm o poder, buscam manter o status quo, porém tudo é um jogo de ação, reação e nova ação: O Estado impõe, a resistência reage, o Estado oprime, a resistência sobrevive. Como Durkheim (apud Latour, 2012, p.64) afirmou:

A unidade do grupo torna-se, pois, visível apenas no emblema coletivo que reproduz o objeto designado por esse nome. 0 clã é, em essência, uma reunião de indivíduos que trazem o mesmo nome e se congregam ao redor do mesmo signo. Elimine-se o nome e o signo que o materializa - e o clã já não é mais representável

Portanto, todos os grupos descritos serão entendidos como agrupamentos que se modificam, adaptam-se e reagem, fazendo mudar suas estratégias e planejamentos. Indivíduos ligam-se a grupos, atraídos uns pelos outros por se sentirem semelhantes e veem nos companheiros e companheiras a sua condição de existência, são, portanto, solidárias (FERNANDA e RODRIGUES, 1990).

\section{AS PRIMEIRAS REAÇÕES À POLÍTICA NEOLIBERAL E O CONTEXTO ECONÔMICO NO FINAL DO SÉCULO XX E INÍCIO DO XXI}

Durante a ditadura militar no Brasil, mais precisamente em 1968 quando o regime demonstrava sua pior fase, passamos por mudanças significativas no campo cultural, uma verdadeira revolução comportamental nos costumes e hábitos de toda uma geração. Houve a grande difusão dos meios de comunicação e a presença da indústria de bens de consumo, contudo a ditadura militar influenciava e vigiava a produção cultural da época. Uma das principais mudanças se deu com o movimento criado por músicos como Caetano Veloso e Gilberto Gil que resgataram os ideais antropofágicos de Oswald de Andrade da década de 1920. Remonta deste período o movimento que chamariam de Tropicália ou tropicalismo, o qual incorporavam elementos da música estrangeira, incluindo o rock e guitarras elétricas (BEZERRA, 2016). Nesse período criaram utopias em busca de engajamento político.

A busca por mudanças e formas de reagir foi diferente das formas tradicionais, uma vez que 0 contexto político era o da ditadura. Além disso, novos temas entravam em pauta como a discussão de gênero 
e etnia, atualizando os problemas discutidos na segunda metade do século XX (GOHN, 2013). A década de 1990 foi marcada pela política macroeconômica no quadro da globalização período no qual discutia-se a possibilidade de outro mundo através de uma "outra globalização" (SANTOS, 2015). Ao debater essas mudanças, também se discutia o neoliberalismo, a economia e seus efeitos nocivos à nossa sociedade (GOHN, 2013). A década seria marcada pelas primeiras reações à política neoliberal que vinha se implantando na segunda metade do século XX:

A ideia da economia centralmente planejada e mesmo a da social-democracia de que 0 Estado poderia até oferecer proteção contra as forças do mercado mundial por meio de protecionismo, da substituição de importações, das políticas fiscais e outros arranjos de bem-estar social foram abandonadas pouco a pouco à medida que os movimentos contrarrevolucionários neoliberais ganharam forças para dominar os aparelhos de Estado a partir de meados da década de 1970 (HARVEY, 2014, p. 223).

A atuação dos movimentos neoliberais em conjunto com o Estado já era uma realidade, e os grupos contra-hegemônicos buscaram trilhar novas formas de ação, pela negação da política tradicional e de forma antissistêmica, criticando as forças do governo e implantando em sua realidade mais horizontalidade (GOHN, 2013; HARVEY, 2014). Passavam agora a combater os resultados da globalização e seus efeitos na economia e no social, especialmente após a crise econômico-financeira de 2008.

Quando Lula (2003-2011) era presidente em 2008, minimizava a crise com a frase: "Lá (nos EUA), ela é um tsunami; aqui, se ela chegar, vai chegar uma marolinha que não dá nem pra esquiar" (GALHARDO, 2008). Voltando um pouco no tempo, o contexto financeiro dos anos de 1990 apresentava países desenvolvidos adotando medidas de liberalização de suas contas financeiras, criando-se um mercado unificado financeiro global. Os Estados Unidos viviam um momento de prosperidade econômica e as medidas liberalizantes intensificaram-se em diversos países. Baixa taxa de juros, aumento da competitividade levaram a redução do lucro dos Estados Unidos, que passou a buscar mercados que pudessem render mais.

Recorreram a empréstimos aos países emergentes e posteriormente o mercado imobiliário americano, utilizaram o mecanismo conhecido como subprime, na qual tomadores de crédito não apresentavam garantias de pagamento, em outras palavras, uma jogada muito arriscada, pois eram firmados contratos de hipotecas imobiliárias com instituições financeiras, ficavam assim sob o risco de crédito. Inicia-se a crise patrimonial, a quebra de diversos bancos, aumento do desemprego e tomadores de crédito que não conseguiram honrar suas dívidas (LIMA e DEUS, 2013). 0 aumento das parcelas das hipotecas levou a inadimplência, o que contribuiu para a crise.

De acordo com Prates (1999), é possível distinguir três fases da globalização financeira, delimitadas por Chesnais (1996). A primeira abrange o período de 1960 a 1979, e caracteriza-se por uma internacionalização financeira indireta e limitada, na qual o mercado financeiro internacional coexistiu com sistemas monetários e financeiros fechados e regulados. A segunda etapa compreende os anos de 1980 a 1985 e é marcada pela implementação, pelos Estados Unidos, das políticas de desregulamentação e liberalização 
financeiras. 0 monetarismo e o liberalismo consistiam na base teórica que sustentava tais políticas. A terceira fase, que se inicia em 1986, tem como marco a generalização da arbitragem e da abertura e desregulamentação das bolsas de valores dos países centrais, a ocorrência de choques financeiros e bolhas especulativas e, a incorporação dos mercados emergentes nesse novo processo de integração (LIMA e DEUS, 2013, p.55).

Compreende-se que a liberalização e desregulamentação financeira liga o mercado financeiro doméstico com o global, demonstrado através da crise do subprime que se espalhou rapidamente pelo mundo e chegando ao Brasil em 2008. Neste período o país encontrava-se com crescimento econômico e usufruía de abundância dos fluxos de capitais e transações comerciais com o mundo. $O$ primeiro efeito sentido no Brasil foi a escassez de crédito internacional fazendo as empresas reverem sua produção e investimento.

A retração causou redução na demanda interna causando parada na atividade econômica no final de 2008, provocando a rápida desaceleração econômica no país. Além disso, com a falência do banco de investimento Lehman Brothers, aumentou a aversão ao risco, desencadeando um movimento de fuga de capitais e desvalorização da moeda brasileira. A economia brasileira desestabilizou-se em 2009, implementando medidas para reduzir os efeitos da crise (LIMA e DEUS, 2013).

Para combater a crise destaca-se as seguintes medidas empregadas pelo governo Lula: 1) a expansão da liquidez, aumentando a disponibilidade de recursos de empréstimos para empresas e agentes financeiros, empresas exportadoras e construtoras; 2) o saneamento do setor financeiro por meio de falências concordatas, ocasionando fusões e aquisições com fundamental papel do Estado a fim de assegurar a economia do país; 3) estatização parcial ou total de agentes financeiros na economia, com injeção de milhões de dólares, como feito na Grã-Bretanha e Estados Unidos; 4) garantia de empréstimos, depósitos e aplicações financeiras; 5) adoção de políticas macroeconômicas monetárias e fiscais, com objetivo de reduzir a taxa de juros e a expansão dos gastos públicos; 6) controle do câmbio e outras medidas que enfocaram em políticas assistencialistas (LIMA e DEUS, 2013). Os resultados dessas medidas foram observados em 2010 no relatório de gestão da Secretaria de Política Econômica com o aumento da liquidez em moeda estrangeira, diminuindo a desvalorização do câmbio, pois manteve o nível mínimo de liquidez, quando a crise estava no seu auge.

O aumento de liquidez no mercado doméstico destacou-se com as instituições financeiras públicas, oferecendo crédito aos setores da agropecuária, bens de produção e consumo duráveis. Houve aumento no setor de construção civil, setor automotivo, maiores vendas de móveis, eletrodomésticos e produção de maquinário agrícola, um maior estímulo do mercado interno, expansão do crédito e desoneração de empresas. A maior parte das medidas tiveram êxito com exceção do preço da moeda, na qual surtiu pouco efeito (LIMA e DEUS, 2013). 
O cenário neoliberal já trazia uma nova lógica, entendia-se que o "dinheiro guia a vida", através da financeirização, cartões de crédito, desemprego, má qualidade do serviço público, privatizações, etc, imperando, neste quadro, a desigualdade social e econômica, com perda dos direitos sociais e exclusão de minorias. Dentro dessa lógica cada pessoa "vale o que tem no bolso". O governo ainda visava a presença do Estado e respeitava valores democráticos liberais, algo que o neoliberalismo desejava destruir.

\section{A SOCIEDADE NEOLIBERAL E A BANALIZAÇÃO DA NECROPOLÍTICA}

O historiador Eric Hobsbawm (1995) observou que os países onde o capitalismo mais se desenvolveu houve a desintegração dos velhos padrões de relacionamento social fazendo-se predominar valores individuais e a destruição de qualquer "socialismo real". Ideais do individualismo liberal sempre estiveram presentes, porém no contexto neoliberal essa política era ainda mais acentuada.

Essa sociedade, formada por um conjunto de indivíduos egocentrados sem outra conexão entrei si, em busca apenas da própria satisfação (o lucro, o prazer, ou seja, lá o que for), estava sempre implícita na teoria capitalista. Desde a Era da Revolução, observadores de todos os matizes ideológicos previram a consequente desintegração dos velhos laços sociais na prática e acompanharam o seu desenvolvimento (HOBSBAWM, 1995, p.25).

As sociedades capitalistas tendem ao processo simultâneo e contraditório de separação dos espaços de produção social e vivência, em que a socialização aconteceria apenas em espaços planejados, mercantilizados e preparados para esse fim, sendo necessário pagamento para seu uso, ou seja, espaços cujo uso para sociabilidade é mediado pelo dinheiro. As relações das pessoas com o lugar e a comunidade passam a ser global, fazendo romper os espaços culturais sendo agora balizados pelo "caráter anti-inercial dos novos capitais, novas mercadorias e pelo poder de globalização das trocas mercantis" (MORAES e COSTA, 1984, p. 89-90). A vivência coletiva, as práticas comunais aos poucos vão cedendo aos fluxos e a nova dinâmica do espaço imposta pela sociedade capitalista.

As práticas sociais dão-se por via das novas tecnologias, bem como as redes sociais que são acessiveis através de aparelhos celulares (smartphones etc) (CASTELLS, 2013). A compra desses aparelhos é explorada e fomentada pelo consumismo capitalista, aproveitando a ampliação da "microinformática doméstica" utilizada para o lazer, cria-se uma cultura da máquina baseada no seu discurso libertador (COULANGEON, 2014). Tais práticas incutiram valor material ao aparelho, capital cultural e uma busca incessante de status. Essa nova dinâmica vai ampliar os espaços incorporados ao processo produtivo, urbano industrial, espaço de lazer para quem pode pagar impõe, assim, o traço caracterizador do novo espaço de vivência. O poder também se move na velocidade dos sinais eletrônicos (BAUMAN, 2008).

A urbanização sob o capitalismo representa, antes de tudo, transformações profundas ao nível das relações sociais como um todo. A afirmação de um novo modo de produção não é, 
como poderia parecer, uma evolução quantitativa da produção ou dos espaços afetos a esse processo. Não há dúvida de que os edifícios, as ruas e praças e todo o universo material de uma cidade, apresenta-se à primeira vista, como provas empíricas de um gigantesco processo de fixação do homem ao solo. Entretanto, o significado real da urbanização contemporânea transcende em muito aquilo que nos é oferecido pela observação de seu aspecto físico. Além do fato de que a cidade capitalista representa para o capital, objeto e meio de realização dos lucros de toda ordem (condição geral de reprodução da produção), o que a transforma em gigantesca massa de capitais privados e capital social geral, ela expressa também uma verdadeira revolução em suas antigas funções de concentradora e dispersora de fluxos (MORAES e COSTA, 1984, p.90-91).

Trata-se da produção de espaços na cidade do Rio de Janeiro através de um empreendedorismo neoliberal ao orientar o planejamento urbano e a realização de eventos para atrair investimento público e privado, também conhecidos como megaeventos (MACHADO, 2017). Segundo Vainer (2013) o planejamento estratégico é adotado pelos governos que se inspiram em conceitos e técnicas oriundos do planejamento empresarial, submetendo a cidade as mesmas condições e desafios que as empresas desejam alcançar. Isso abriria para o debate sobre uma competitividade urbana, na qual as cidades disputam como empresas, avaliando-se qual pode empreender e mercantilizar mais seu espaço e gerar mais lucros, eis a lógica capitalista e seu modelo neoliberal.

Ver a cidade como empresa é concebê-la como agente econômico que vai atuar dentro de um contexto de mercado, seguindo regras e um modelo de planejamento, agindo estrategicamente, empresarialmente e tomando decisões a partir de expectativas geradas pelo mercado (VAINER, 2013). Cada indivíduo que faz parte da cidade é interpelado como "aliado" para ajudar a fazer o país crescer, esse deve ser o projeto de vida de cada cidadão, essa é a forma que a necropolítica neoliberal encontra para fazer calar e destruir qualquer reflexão sobre a sociedade (GEFAELL, 2015).

O Rio de Janeiro é colocado em disputa no mercado neoliberal, sendo usada para realização de megaeventos, fazendo parte da urbanização pelo capitalismo através da ótica do neoliberalismo. Esse projeto causa impactos e transformações significativas no espaço urbano, uma mercantilização da vida e enfraquecimento dos direitos e garantias conquistados (MACHADO, 2017). São projetos urbanos de reestruturação da cidade através do megaevento esportivo em uma parceria público privado, partindo primeiro da tentativa de convencer a opinião pública, sobre o argumento que tais mudanças na estrutura favoreciam a população posteriormente, esse seria o que Vainer (2013) chamaria de Markting Urbano.

Demonstra-se o fim da separação entre setor público e privado, e "privado aqui é, claramente, o interesse privado dos capitalistas e, neste sentido, comparece no mesmo campo semântico de expressões como iniciativa privada, privatização e outras, que evoquem ou remetem a capital, capitalistas, empresários capitalistas" (VAINER, 2013, p. 88). Esse processo não é apenas administrativo ou gerencial, mas com essa atuação o conceito de cidade, poder público e governo tomam novos significados, o que faz mudar 
drasticamente o uso do espaço urbano e o direito ao uso desse espaço pelo povo, pois a partir dessa nova dinâmica compreende-se que o espaço é direcionado para produtividade e competitividade, negando-se qualquer atividade democrática como o protesto político democrático, pois esse não gera lucro.

A partir de 2009 o poder público olhou com mais interesse para o espaço urbano do Rio de Janeiro e implementou seu "Plano Estratégico da Cidade do Rio de Janeiro (2009-2012) - pós 2016: o Rio mais integrado e competitivo" apresentado pelo recém eleito Eduardo Paes, em seu primeiro mandato (2009 2012), O novo prefeito apresentava sua agenda e visava a proteção e recuperação dos espaços públicos, igualdade e oportunidade para jovens e crianças; estabelecer condições para o crescimento econômico sustentável; desenvolver setores estratégicos para a economia carioca; tornar o Rio uma cidade mais integrada (do ponto de vista urbanístico e cultural); reduzir os níveis de pobreza e indigência e posicionar 0 Rio como importante centro político e cultural no cenário internacional (PREFEITURA DO RIO DE JANEIRO, 2009).

Como ordem pública o governo entendia que "nos últimos anos, o espaço público no Rio de Janeiro deixou de ser visto como o espaço de todos para ser visto como espaço de ninguém" (Prefeitura do Rio de Janeiro, 2009, p. 58), apontando como problemas: 1) desrespeito às normas de trânsito e aos limites de estacionamento; 2) expansão do comércio irregular no espaço público; 3) proliferação do transporte coletivo; 4) aumento da população de rua e 5) crescimento das ocupações ilegais no asfalto e nas comunidades. Com metas apresentadas em ter um efetivo de pelo menos 3000 guardas municipais até 2012; implantar 400 novas câmeras de segurança e formalizar 25000 comerciantes que operam no espaço público (Prefeitura do Rio de Janeiro, 2009, p. 60).

Trata-se de uma proposta que buscou implantar no decorrer dos anos de governo sua política de segurança pública, mas o que era observado diariamente era o desrespeito a toda e qualquer dinâmica das práticas sociais locais, perseguindo ambulantes, comerciantes, ocupações artísticas e simbólicas as substituindo por outro tipo de comércio e práticas culturais ligadas ao projeto olímpico de 2016 (MACHADO, 2017). Mas, tais medidas não teriam começado na prefeitura de Eduardo Paes, o "choque de ordem" já acontecia em 2007 (com o prefeito César Maia e o governador Sérgio Cabral) com a realização dos Jogos Pan-Americanos, seguido de uma agenda quase anual de eventos até a Copa do Mundo da FIFA em 2014 e os Jogos Paraolímpicos de Verão em 2016 (MACHADO, 2017). Compreende-se que o interesse em "colocar em ordem" a cidade visava prepará-la para um projeto de mercantilização e dinamizá-lo para os interesses neoliberais.

Dentro desse contexto, é importante destacar que a realização de megaeventos não ficou restrita ao âmbito esportivo, alcançando também o campo cultura, fazendo que determinados bens passassem a ser tratados como "produtos turísticos", justamente por serem mecanismos necessários às intervenções planejadas. Com base nessa lógica, foram realizados festivais musicais, feiras gastronômicas, eventos de moda, cerimônias religiosas e festas populares, dentre as quais se destaca o Carnaval de Rua da cidade [...] essa 
dinâmica gerou não só conflitos, mas também graves violações dos direitos humanos. Nesse cenário, enquanto muitas ações sociais foram desenvolvidas a fim de legitimar 0 projeto de reestruturação urbana aplicado pelo Poder Público, outras diversas se desdobraram de maneira totalmente oposta (MACHADO, 2017, p.22).

A cidade é adequada e adaptada para o consumo e sua imagem é demonstrada ao mercado externo, com abertura seletiva apenas para consumidores e não imigrantes pobres (VAINER, 2013). Um "urbanismo olímpico", com ressignificação de locais já ocupados, criando novos territórios envolvidos com circuito imobiliário para tornar-se uma cidade espetáculo, para consumo global, uma cidade reinventada e adaptada para as estratégias comerciais (FREITAS, SANTOS e LINS, 2017).

A venda da imagem da cidade segura muitas vezes vai junto com a venda da cidade justa $e$ democrática. No diagnostico produzido pelo Plano Estratégico do Rio de Janeiro, com assessoria de consultores catalães, a cidade é apresentada como "laboratório de experimentação e aperfeiçoamento democrático, baixa intolerância racial e exemplo de harmonia social (sic)". (VAINER, 2013, p.81).

A "a cidade não é apenas uma mercadoria, mas também, é, sobretudo, uma mercadoria de luxo, destinada a um grupo de elite de potenciais compradores: capital internacional, visitantes e usuários solváveis" (VAINER, 2013, p. 83). É o controle urbano, por meio do Choque de Ordem, citado no site da prefeitura do Rio, como uma forma de "pôr fim a desordem" da cidade (RIO, 2009). (Figura 1)
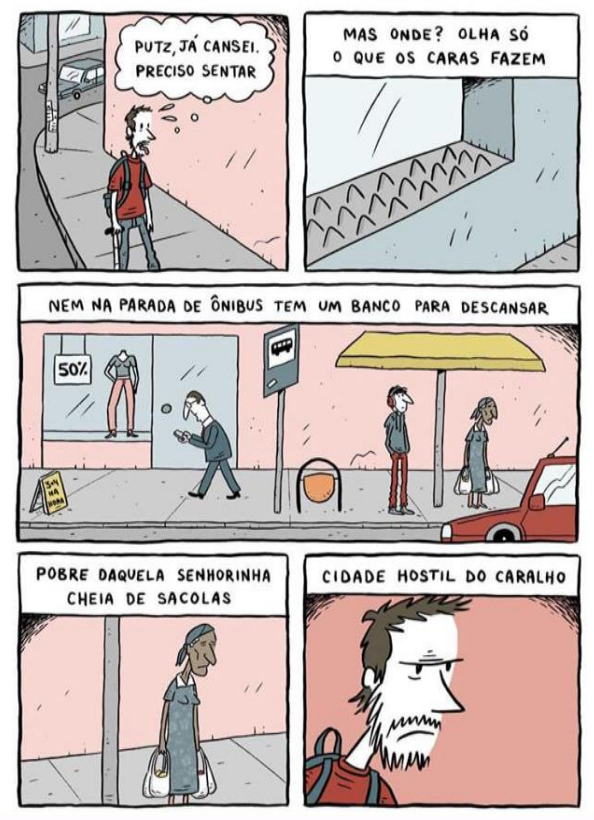

Figura 1 - Memórias de um esclerosado Ilustração: CORRÊA, 2019.

A eficácia dos ajustes espaciais também leva a constante produção da pobreza e de sua invisibilidade a diferença social não é solucionada, mas apenas mascarada, sendo assim uma pobreza planejada 
(SANTOS apud SILVA, 2015). O plano estratégico citado também se preocupa com qual fim dará a população de rua, mas busca em primeiro lugar sanar um "problema" paisagístico, sumindo com pessoas ou instalando placas "acústicas" que na verdade servem para tapar a visão das comunidades pobres da cidade, o Rio de Janeiro é preparado e maquiado para receber seus consumidores. O planejamento urbano não vai só pensar a estrutura da cidade, mas vai planejar também como tornar a pobreza invisível aos olhos de quem vem consumir.

Os cidadãos que não vivem nessa condição de pobreza, são levados a desconfiar dos excluídos, pois o sistema neoliberal divide a sociedade e inculca o individualismo, fazendo-se acreditar que quem é pobre, "não se esforçou o bastante", princípios do que chamamos de "meritocracia". A cidade hostil e segregacionista corrobora para uma necropolítica neoliberal, compreendido nesse artigo a forma como governos que matam com sua polícia e deixam morrer com políticas de exclusão, morrem os sem-teto, doentes crônicos, refugiados, marginais, emigrantes, ou seja, corpos não rentáveis são deixados para morrer, a partir da invisibilidade, se deixa morrer quem não é rentável ou interessante para o Estado neoliberal.

O Estado exerce seu poder pelo controle do espaço, mas também através das relações-públicas e a mídia a fim de induzir a passividade. Tais técnicas, segundo Chomsky (2013), não são novas, mas assumem formas novas conforme as circunstâncias da ideologia no contexto histórico, como por exemplo, alegar déficit do orçamento, crise financeira ou reforma da previdência, assuntos muitas vezes complexos de entender. Diante da necropolítica neoliberal, não queremos ser escravizados, assassinados ou oprimidos, então resistimos, criamos grupos e lutamos. Essa resistência também vai gerar novas reações de quem detêm 0 poder, buscando estratégias de dominação, armadilhas mentais, uma "escravidão mental" (CHOMSKY, 2013, p.101). São doutrinas que não são afirmadas formalmente, mas em forma de pressupostos, com referências e fazendo joguetes mentais de convencimento através do uso da mídia, discursos complexos, notícias falsas, incutindo sentimento de medo ou criando um inimigo.

O Estado baseado na necropolítica neoliberal tem poder sobre a vida, nomeado de biopoder, o direito de matar (da polícia) legitimado e o direito de deixar morrer (negar investimento na saúde). Deixa que morra lentamente e de forma dolorosa aqueles que dependem da saúde, em listas de espera de transplante, operação ou sem medicamentos, como doentes nos hospitais (GAFAELL, 2015).

A necropolítica também uma forma de guerra, visando a destruição dos corpos humanos e fazendo com que nós, a população, conviva com isso, banalize a violência e normalize essa condição (MBEMBE, 2016). Na concepção de Mbembe (2016) o biopoder foucaultiano é associado à ideia de Estado de exceção e Estado de sítio e apela continuamente para a noção de inimigos a serem eliminados. Na noção de biopoder alguns devem viver e outros morrer, fazendo-se distribuir as pessoas em grupos e subgrupos (FOUCAULT apud MBEMBE, 2016). Como exemplo histórico, teríamos o regime Nazista na segunda guerra mundial e suas atrocidades, essa noção também pode ser observada nas execuções públicas, na forca e na Revolução 
Francesa. Também, se analisa a escravidão no Brasil como uma das primeiras instâncias de biopolítica, pois "pretos e pretas" foram privados de suas terras, o direito sobre seus corpos e vendidos como mercadoria, representa assim a dominação absoluta, a morte social.

O poder sobre a vida do outro assume a forma de comércio: a humanidade de uma pessoa é dissolvida até o ponto em que se torna possivel dizer que a vida do escravo é propriedade de seu dominador. Dado que a vida do escravo é como uma "coisa" possuída por outra pessoa, sua existência é a figura perfeita de uma sombra personificada (MBEMBE, 2016, p.132).

Como descrito anteriormente, o investimento será no aparato policial a fim de colocar ordem na cidade e fomentar a força policial para lidar com o público, isso é desrespeitar a dinâmica do espaço demarcando uma das características da necropolítica,

Esse Estado, ele (Foucault) afirma, tornou a gestão, a proteção e o cultivo da vida coextensivos ao direito do soberano de matar. Por uma extrapolação biológica do tema do inimigo político, organizando a guerra contra os seus adversários e, ao mesmo tempo expondo seus próprios cidadãos à guerra, o Estado nazista é visto como aquele que abriu caminho para uma tremenda consolidação do direito de matar, que culminou no projeto da "solução final". Ao fazê-lo, tornou-se o arquétipo de uma formação de poder que combinava as características de Estado racista, Estado assassino e Estado suicidário (MBEMBE, 2018, p.19)

Um Estado moderno, como o Rio de Janeiro guarda todos esses elementos. Tal política fica ainda mais clara com a entrada no governo de Wilson Witzel do Partido Social Cristão - PSC (a partir de 2019), até então um candidato que não aparecia como favorito nas eleições, mas ganha notoriedade quando passa a declarar abertamente seu apoio a presidência de Jair Bolsonaro (Partido Social Liberal -PSL). Witzel defendia as ideias do candidato do PSL e ia aos debates com adesivos de Jair ao peito. Após eleito, Witzel também foi polêmico ao afirmar que a cidade precisaria ter atiradores de elite, prontos para abater quem estivesse portando armas, "a política vai mirar na cabecinha e... fogo"; em outro momento, na operação em Angra dos Reis, o governador acompanhou a operação de helicóptero, durante o voo na região, os policiais dispararam tiros em uma lona azul cercada de grama no topo de um morro, usada por religiosos para orar, teriam confundido o abrigo com ponto de encontro dos criminosos, por sorte não havia nenhum fiel no lugar.

O episódio mais invulgar na história do Rio de Janeiro foi quando um homem armado com uma arma de brinquedo sequestrou um ônibus e fez 37 reféns na ponte Rio Niterói e seu trágico desfecho. 0 homem, identificado como William Augusto da Silva, de 20 anos, também estava portando combustível e ameaçava incendiar o ônibus, tendo-se alegado nos meios de comunicação social que o mesmo estava em surto psicótico (NITAHARA, 2019). William acabou sendo morto por um atirador de elite às 9h. Após quarenta $e$ cinco minutos depois Witzel chegou de helicóptero, descendo da aeronave e fazendo gestos de comemoração com punhos cerrados (CORREIO BRASILIENSE, 2019). Demonstra-se o direito do soberano de matar e comemorar uma vitória sobre "o inimigo". 
Hoje o Estado ainda exerce controle sobre os corpos das pessoas pretas, impondo a submissão e alienação da população, configurando o trinômio: disciplina, biopolítica e necropolítica. Porém, Mbembe (2016) considera que a noção de biopoder é insuficiente para explicar a complexibilidade contemporânea em que o Estado subjuga a vida e decide quem morre, propondo então a noção de necropolitica e necropoder, que se acredita representar a nossa realidade no Rio de Janeiro em 2019 e também de outros espaços urbanos de forma mais generalizada. Trata-se de uma violência direta e disfarçada, reprimindo as pessoas que reivindicam seus direitos rotulando-as como terroristas, extremistas ou vândalos, como destacou Gafaell (2015), e essa é exatamente a política apresentada pelo ex-prefeito Eduardo Paes, seu sucessor Crivella e o atual governador Wilson Witzel. Abro esse debate as demais regiões do Brasil, como também pode ser observado na política de João Doria (o Bolsodoria como ele divulgou também em sua candidatura) em São Paulo e sua perversa política contra os pobres.

\section{O PROCESSO DE CONVENCIMENTO E O PAPEL DA MÍDIA}

O planejamento da propaganda é um fator fundamental para o convencimento e mudança de mentalidades de uma sociedade. Mas, para que a população aprove essas mudanças precisa ter uma generalizada consciência de crise, através da degradação da infraestrutura urbana, o sucateamento da saúde e educação, a fim de justificar a urgência de respostas que se dará pela negociação do setor público com 0 privado para a paz entre conflitos internos. A educação que já passava por uma crise de filosofias herdadas ainda é entregue às forças difusas e não coordenadas do mercado (BAUMAN, 2008).

[...] não é a crise em si o elemento decisivo, mas sim sua percepção. Trata-se aqui das condições subjetivas da trégua e da paz sociais, da abdicação, por parte de diferentes atores (todos?), de seus interesses particulares... somente assim um projeto unitário, coeso, legítimo e universalmente aceito poderá ser levado adiante (VAINER, 2013, p.93).

Isso ficou muito claro no Brasil com o golpe contra a ex-Presidenta Dilma Rousseff em 2016, na qual foi criado todo um cenário de crise com a construção de um único inimigo que deveria ser erradicado: 0 Partido dos Trabalhadores (PT). O projeto visava uma "guinada à direita", o que acabou abrindo espaço para as promessas e vitória de Jair Bolsonaro para Presidente em 2019 e seu ministro da economia, Paulo Guedes, que vinha com sua agenda neoliberal para a economia.

Para compreendermos o golpe no Brasil é necessário observar o cenário político na América Latina, com a vitória de Hugo Chàvez na Venezuela (1998), Ricardo Lagos no Chile (2000); Lula no Brasil (2002); Néstor Kichner na Argentina (2003); Tabaré Vásquez no Uruguai (2005); Evo Morales na Bolívia (2006); Michelle Bachelet no Chile (2006); Rafael Correa no Equador (2006); Daniel Ortega na Nicaraguá (2006); Fernando Lugo Paraguai (2008); Maurício Funes em El Salvador (2009); reeleição de Rafael Correa no 
Equador (2009); Mujica no Uruguai (2009) e Evo Morales reeleito na Bolívia (2009) (HARNECKER apud QUIRINO e GUAZINA, 2017), os governos apresentados tem em comum a posição política de esquerda ou de centro-esquerda. No Brasil tivemos as sucessivas eleições de Lula, seguindo com a vitória de Dilma Roussef como primeira presidenta da República e ambos os candidatos do Partido dos Trabalhadores - PT.

Os golpes começaram em Honduras (2009) e no Paraguai (2012), depois no Brasil (2016), uma tentativa na Venezuela (2019) e depois na Bolívia (2019), demonstram as sucessivas tomadas de governo com características em comum. Também é importante observar que os governos na América do Sul fossem de esquerda, nenhum deles tentou iniciar uma transição ao socialismo (LÖWY, 2016), em diferentes medidas buscaram algum diálogo com as frentes liberais e social democrata, os golpes não seriam por nenhum medo ao comunismo, mas sim pela falta de vontade de dialogar e a imposição de outro sistema econômico mais agressivo.

Dentro desse cenário, o Brasil viveu a disputa entre o campo político neoliberal - representando a burguesia nacional integrada ao capital estrangeiro, que buscava a abertura comercial ampla, compra e venda de estatais - e a frente política heterogênea, chamada de neodesenvolvimentista, que agrupava a burguesia interna, parte da baixa classe média, campesinato e trabalhadores de massa marginal.

A frente heterogênea era representada pelo governo petista que buscava o estímulo do crescimento econômico nacional, a distribuição de renda e implementar a política cultural mais favorável às minorias. Esses dois campos disputam espaço entre 2003 e 2014, destacando-se entre 2006 e 2012 o campo neodesenvolvimentista. Em 2013 a burguesia inicia sua ofensiva contra o governo de Dilma Roussef (20112016), buscando restaurar a hegemonia do campo neoliberal (BOITO JR., 2016).

Para Armando Boito Jr. (2016) três acontecimentos colaboraram para o golpe: 1) a alta classe média passa a ser ativa no processo político por causa das manifestações de 2013; 2) A deserção da grande burguesia interna, retirando seu apoio ao Partido dos Trabalhadores e passam a apoiar os neoliberais, tal como a Fiesp que toma a frente da ofensiva burguesa contra o partido; 3) A crise da frente neodesenvolvimentista e o recuo do governo Dilma diante dessa situação.

O golpe político, no Brasil foi desferido a jato. Mas sua preparação levou anos, com 0 trabalho de deslegitimação dos governos eleitos, levado a cabo pela mídia, pelos institutos privados destinados à disputa ideológica e pelos movimentos pretensamente "espontâneos", mas que, como já está comprovado, foram financiados e treinados por fundações estadunidenses (MIGUEL, 2016, p.34).

Os protestos de 2013 foram mais bem aproveitados pela direita, a apropriação da indignação, das cores, da bandeira e até do hino nacional, exageraram para um discurso nacionalista que buscava mais intimidade e proximidade com o brasileiro, para assim, convencer aqueles que ainda estavam em dúvida, qual caminho seguir. Dentro desse cenário de verdadeira doutrinação Paulo Freire tornou-se um símbolo a ser 
combatido, como representante da "doutrina marxista", estava iniciada a perseguição ideológica contra a esquerda.

A mídia se fez presente durante o golpe, influenciou e ajudou a fomentar a percepção de crise. Observa-se que dos protestos ocorridos desde 2013, das 50 notícias no Primeiro Caderno do jornal da Folha de São Paulo, 18 foram sobre os protestos contra impeachment, 16 de Protestos pró-impeachment e 16 sobre a aceitação do pedido de impeachment (QUIRINO e GUAZINA, 2017). Boa parte das notícias voltadas para protestos contra o impeachment eram relacionadas a prisões e tinham foco no "vandalismo" dos manifestantes, ao contrário que as manifestações pró-impeachment, demonstravam o quanto o protesto era "democrático" e excessivamente verde e amarelo.

Quirino e Guazina (2017), também fizeram estudo qualitativo das notícias, analisadas; os protestos contra o impeachment destacam notícias sobre financiamentos de protesto pelo governo ou terrorismo encabeçados pelo PT, a fim de desmerecer os protestos. Já nos protestos pró-impeachment os enquadramentos enfocam a seriedade ou situações absurdas como a "tietagem" aos policiais tirando selfies com manifestantes.

O Rádio e a Televisão contribuíram bastante para o cenário, noticiando diariamente e em todos seus telejornais a situação de uma possível crise, levando ao pânico e apreensão da alta Burguesia, a televisão, em especial o Jornal Nacional da Rede Globo de Televisão, foi um dos principais fomentadores do clima de crise, ajudando no processo de convencimento da opinião pública contra o governo de Dilma Roussef e a constante criação de um inimigo, o Partido dos Trabalhadores. 0 jornalismo tem a função de informar, mas também é uma instituição política, e constroem a realidade a sua maneira, de acordo com interesses. Nesse período ficou bastante conhecido o termo "imprensa marron" que relacionava-se a essa imprensa que tinha outros interesses e não a informação imparcial.

\section{NEOLIBERALISMO EM CURSO: O GOLPE}

Em 2 de dezembro de 2015 o presidente da Câmara dos Deputados, Eduardo Cunha (do Partido do Movimento Democrático Brasileiro- PMDB) abriu o processo de impeachment contra a presidenta, alegando 0 crime de responsabilidade fiscal com base na lei orçamentária e à lei de improbidade administrativa, buscando enquadrar as "pedaladas fiscais", mecanismo utilizado até então por tantos outros presidentes até aquele ano. Em 29 de março de 2016 o PMDB conseguiu tirar Dilma do governo. Assume seu vice Michel Temer (também do PMDB) demarcando o início do golpe neoliberal no Brasil. Dois dias depois do impeachment o Senado Federal sancionou uma lei que flexibiliza as regras para a abertura de créditos suplementares, em outras palavras, tornaram "legal" as pedaladas fiscais que foram utilizadas como argumento para retirada de Dilma do poder. 
Nesse cenário de ativa participação da população na "novela" política, e constante inculcação da mídia golpista, fez grande parte da população generalizar a política como "coisa de gente corrupta". Essa visão generalista não era uma novidade, porém nesse momento histórico ganhava ainda mais potencialidade, pois a partir de 2013 , com a população mais atenta a política, porém não mais informada, se encontrava mais exposta ao discurso manipulador de alguns salvadores da pátria.

Uma figura até então meio apagada na política, que chamava a atenção por suas declarações polêmicas, homofóbicas e sexistas, o então Deputado Jair Bolsonaro começou a despontar como favorito para as eleições. O levantamento da Ordem dos Advogados do Brasil (OAB) apontava em 2015 que 91\% dos brasileiros dizem não confiar em partidos políticos (CLETO, 2016). Cria-se um espaço vazio, que prontamente é preenchido por gente de discurso raso, moralista e religioso, os "salvadores da pátria", figuras que eram romantizadas desde o "Japonês da Federal2" ao Juiz Sérgio Moro, que comandou o julgamento em primeira instância dos crimes identificados na Operação Lava Jato ${ }^{3}$. Não é a toa que ainda hoje alguns dizem que votariam em Moro para presidente caso esse se candidatasse para a eleição. (Figura 2).

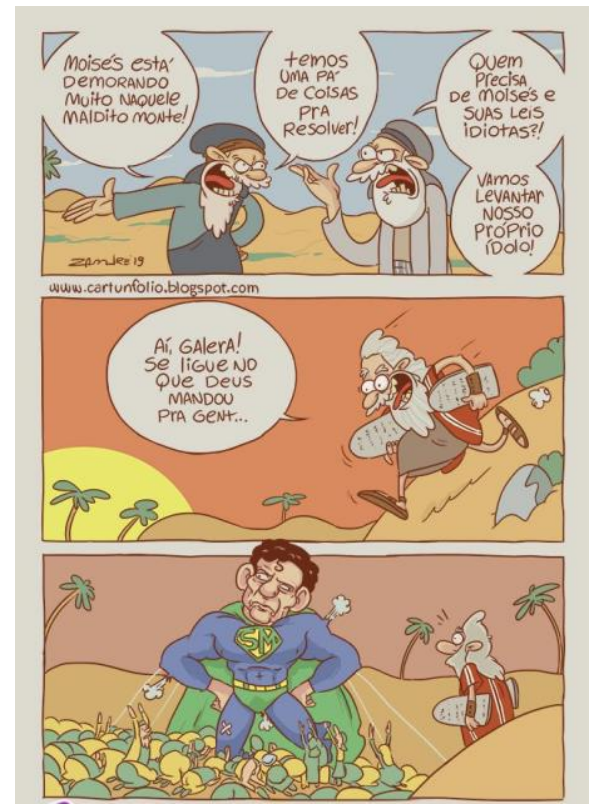

Figura 2 - Bezerro de Latéx - 2019 Ilustração: ZANDRÉ, 2019.

A pesquisa feita em 2018 pelo instituto da Democracia e da Democratização, para avaliar o nível de satisfação da população com a democracia e com a conjuntura política no Brasil, verificou que os últimos três

\footnotetext{
2 Newton Ishii conhecido por conduzir presos na Operação Lava Jato, foi preso em 2016 por facilitação de contrabando (JUSTI; DIONÍSIO, 2016).

3 Foi um conjunto de investigações da Policia federal do Brasil a fim de apurar o esquema de lavagem de dinheiro que envolvia membros administrativos da empresa estatal petrolífera Petrobras.
} 
anos houve mudanças importantes no comportamento, atitudes e nos valores dos cidadãos brasileiros com relação à democracia e a seu funcionamento. Demonstrou ainda um déficit muito significativo no baixo grau de confiança e na avaliação das instituições, recusa da política, dos partidos e uma percepção negativa da legitimidade do sistema (MENEGUELLO, AMARAL e SIMONI JR, 2018).

Destaca-se que "os padrões de satisfação dos brasileiros com o regime democrático encontra-se nos níveis mais baixos desde 2002", sendo que $30,3 \%$ dos brasileiros demonstravam satisfação em 2002, crescendo o valor percentual nos anos seguintes até 2010, com 44,4\% e decrescendo a partir de 2014 , chegando ao mínimo de 19,4\% em 2018 (MENEGUELLO, AMARAL e SIMONI JR, 2018, p. 4-5). Os dados demonstram que a população começa a sentir confiança no governo a partir da vitória de Lula e perdem confiança com o início do golpe.

É notável Dilma foi reeleita com 54,5 milhões de votos, o processo de golpe, que anula a vontade dessas pessoas foi uma grande afronta, junto a isso toda avalanche de notícias acerca da Operação Lava Jato e todo processo de inculcação do inimigo. Soma-se a isso o medo do cidadão, o descrédito com a política e como já foi citado, o crescente aparecimento dos "heróis da pátria", com suas promessas absurdas.

Vale ressaltar também que os níveis de satisfação com a democracia e a adesão ao regime militar em que os moradores do Sul, Norte e Centro Oeste estão menos satisfeitos com a democracia em comparação com moradores do Sudeste e moradores do Nordeste apresentam chances similares aos habitantes do Sudeste. A pesquisa ainda apontou que a maior parte dos brasileiros concorda com a condenação do expresidente Lula e que o impeachment de Dilma Roussef foi um golpe.

Considero que essa pesquisa reflete que a construção do golpe obteve parte do sucesso, pois conseguiram fabricar um "bode expiatório", Lula acabou se tornando a "vítima sacrificial", porém quando Dilma conseguiu demonstrar sua total inocência, os golpistas não conseguiram sustentar a tese de corrupção, ficando claro que a ex-presidenta fora retirada injustamente do poder (MENEGUELLO, AMARAL e SIMONI JR, 2018, p.14). O nível de concordância com a condenação do ex-presidente Lula, mesmo ainda sendo apoiada pela maioria dos brasileiros fica com percentual de 30,3\% daqueles que concordam muito; $15,2 \%$ concordam pouco contra $27,6 \%$ que discordam muito e $11,5 \%$ que discordam pouco, com $10,3 \$$ neutros e $5 \%$ que não responderam (MENEGUELLO, AMARAL e SIMONI JR, 2018).

Observa-se que esses valores estão próximos e não são tão discrepantes, demonstrando que mesmo com sucesso, todo o processo de inculcação ao longo dos anos pouco menos das pessoas discordam da condenação de Lula. Esses dados são importantes para observar o quanto do processo de construção do golpe e seus resultados surtiram efeito no momento da eleição e quais percepções mantiveram-se dessa longa construção. Gostaria de pontuar também que Lula teve um dos julgamentos mais rápidos da história, julgado em menos de seis meses (outros casos levavam mais de um ano), fazendo-se desconfiar de uma tentativa de inviabilizar a candidatura de Lula em 2018, sendo solto 580 dias depois por decisão do Supremo 
Tribunal Federal4. Existe também o valor simbólico por parte dos golpistas, um "troféu" como o Lula na cadeia seria impactante para demarcar a "vitória" de certos "heróis" como o juiz Sérgio Moro.

Nesse contexto decorre um processo constante de despolitização, e isso, começa com a repressão dos protestos políticos de rua, sua criminalização e perseguição, que infelizmente já era uma característica desde antes do golpe, mais acentuada depois dele. O governo deve parecer coerente e forte, e busca elementos de uma liderança carismática.

Observa-se assim que a partir de 1980 teremos um novo tipo de poder que está inscrito em três esferas: 1) esfera do mercado, através das novas práticas de mercantilização do espaço; 2) esfera política, representada pelo marketing político dessas novas práticas; 3) esfera cultural, na qual atua a indústria cultural, publicidade, pesquisa de mercado e o marketing. Essas esferas geram novas redes de influência (SILVA, 2015, p.38). Todo esse processo de marketing também vai atuar na produção de comportamentos que sejam afinados com a lógica da cidade, fazendo assim modificar as práticas das pessoas que nela vivem. Essa população vai adquirir novos hábitos e costumes, moderniza-se o consumo fazendo aumentar o lucro de grandes grupos que competem de forma desigual com o pequeno comércio local.

Degrada-se o do espírito crítico, fazendo as mudanças parecerem naturais. 0 desencadeamento vai levar o pobre a ficar cada vez mais endividado (XAVIER, 2014). As pessoas passam a ver as diferenças de forma relativizada e distante. Além disso, ao modificarem o espaço urbano, vão reforçar as ideias consumistas: uma praça antiga, ponto de encontro entre amigos e lazer pode virar um shopping se tornar a frente de um grande mercado, fazendo mudar nosso comportamento de acordo com o espaço:

O humilde habitante tem seu sistema de significações (ou antes seu subsistema) ao nível ecológico. $O$ fato de habitar aqui ou ali comporta a recepção, a adoção, a transmissão de um determinado sistema [...]. O sistema de significações do habitante diz das suas passividades e das suas atividades; é recebido, porém modificado pela prática. (LEVEBRE, 2001, p.111).

Outros fatores são apontados por Manuel Castells (2019) para a total desmobilização da população, um deles, o desmantelamento da educação, que visa desconstruir a informação básica, a capacidade de opinião e questionamentos que impediriam essas pessoas de aceitarem um estado opressor. Numa sociedade neoliberal o princípio de solidariedade presente na educação pública pode soar errado, pois os novos valores são baseados na individualidade, portanto, pagar impostos para outro estudar parece errado (CHOMSKY, 2013). A mentalidade neoliberal está presente desde o governo de Michel Temer e vem com mais força no constante desmonte da educação no governo de Jair Bolsonaro, como por exemplo, o corte de verbas de três Universidades Federais: a Universidade Federal Fluminense (UFF), Universidade Federal da

\footnotetext{
4 Foi decidido por 6 votos a 5, que o condenado só poderia ser preso após o trânsito em julgado, alterando a jurisprudência que permitia a prisão logo após a condenação em segunda instância. A soltura foi determinada pela juiz federal Danilo Pereira Junior (BARAN, 2019).
} 
Bahia (UFBA) e a Universidade de Brasília (UnB), que tiveram um bloqueio de $30 \%$ das verbas. 0 ministro Abraham Weintraub alegou que as universidades que estivessem fazendo "balbúrdia" teriam suas verbas reduzidas. $O$ que não ficou entendido eram quais critérios de avaliação seriam usados para avaliar o que era "balbúrdia" (AGÊNCIA SENADO, 2019).

Para Miguel (2018) três são as vertentes da extrema direita no Brasil: o libertarianismo, que busca o livre mercado como os liberais, mas são contra qualquer forma de solidariedade social; o fundamentalismo religioso e a reciclagem do anticomunismo (do tempo da guerra fria), cujos cristãos fundamentalistas reforçavam (i) o discurso da família tradicional, culpando o Estado por retirar a autonomia patriarcal e proteger o núcleo familiar (entendido por eles como somente homem, mulher e filhos); (ii) defendiam uma "verdade" absoluta e (iii) confiavam apenas em seus líderes religiosos, assumindo estes o papel dos novos coronéis da política brasileira; e a terceira vertente, os anticomunistas que fazem novos discursos contra um "bolivarianismo" venezuelano.

Essa estrutura da direita no Brasil também é observada por Carapanã (2018), apontando à apologia ao eugenismo e segregação racial, presentes em ideias conservadores e reacionários, fazendo com que essa nova direita recuse a democracia liberal. Esses grupos não mensuraram o poder de influência das suas ideias na opinião pública, nos fiéis da igreja e nos espaços "não ocupados pelo Estado", nomeadamente na periferia e subúrbios do Rio de Janeiro, onde o poder paralelo tem forte influência.

É possível observar que a subordinação da população (da classe trabalhadora) é fenômeno recorrente desde meados do século XVIII com a mudança do caráter da população e o aparecimento das primeiras máquinas a vapor e o sistema fabril, criando condições de trabalho e alienação com a redução do tempo livre, a perda do tempo para qualquer tipo de reflexão (THOMPSON, 1987). Em nosso tempo os mecanismos de alienação são atualizados com as novas tecnologias, como a mídia já citada.

O controle da informação e da comunicação levaria a manipulação das mentes (o controle mental) e emoções de forma mais eficaz. Um governo com posicionamento anti-humanista, desprezo geral pela democracia, guerra contra pobres, pretos, mulheres, religiosos (contra muçulmanos) e minorias (como os deficientes), seria perfeito para tal desmobilização. Dessa forma a necropolítica neoliberal convence que 0 futuro é a contínua violência e ameaça constante, necessitando da total entrega da população aos valores sagrados, hierárquicos, religioso (único e cristão) e tradicional como forma de salvação (MBEMBE, 2016). promessas de combate à violência com mais violência será satisfatório para essa população, e talvez até promessas de armamento livre para todos fazerem justiça como julgarem melhor.

Presentismo, plenitude e consumismo se mesclam dentro dessa nova realidade, serão esses fenômenos de desintegração social e cultural da sociedade, que são fomentados por diversas estratégias, desde a coação e persuasão ideológica até a prática da violência e terror de Estado. O poder político procura 
organizar a infraestrutura urbana mantendo a população insatisfeita sob controle (HARVEY, 2014). Muda-se as mentalidades e a estrutura de nossa sociedade.

Parte dessa mudança vem com a onda anti-petista que tomou espaço na mídia e na internet, diante dessa situação Jair Bolsonaro foi ganhando mais visibilidade e ascendendo politicamente. No estudo de Márcio Moretto Ribeiro (2018) ao observar as redes sociais (Facebook) e as páginas mais relevantes em número de leitores, notou-se através da ferramenta de compartilhamentos de notícias algumas tendências em comum: algumas páginas de direita centralizavam as identidades e notícias em comum.

Ribeiro (2018) comparou os compartilhamentos entre páginas e notou três grandes concentrações, chamadas pelo autor de "clusters": policial (páginas como "Eu nasci pra ser Polícia", "Amigos da Rota", "Coronel Telhada", "Major Olímpio"), patriotas ("Mobilização Patriota", "Em Defesa do Brasil", "Pátria Amada Brasil" e "Patriotas Brasil") e conservadores ("Livres", "Liberalismo zoeira", "Novo 30", "Mises Brasil", "Instituto Liberal", "Jovens de direita", "Sempre Família" etc.). Entre os três clusters estava um quarto grupo, eram as páginas: "Ex Otário", "Homens diferenciados", "MBL”, "Kim Kataguiri”, "Eduardo Bolsonaro" e "Jair Bolsonaro".

Durante esse tempo o cluster central compartilhava e era compartilhado por todos os outros três outros clusters. Observo que esse seria um dos fatores fundamentais na propagação das notícias, propaganda e os famosos Fake News ${ }^{5}$, fazendo agregar cada vez mais admiradores as páginas centrais, como a de Jair Bolsonaro e sua família. Esse cluster central proferia discurso contra a esquerda extremista e destacava-se por mensagem de cunho patriótico e religioso. E a figura que mais chamou a atenção foi Jair Bolsonaro, por seus discursos extremistas, angariando cada vez mais novos adeptos. A esquerda incrédula não acreditava que tal figura "folclórica" pudesse chegar à presidência do Brasil, portanto desdenharam e claro fizeram piada da possibilidade.

Essa forma de manipular as mentalidades era algo novo na política, deve-se lembrar que no ano de 2016, Donald Trump distribuiu notícias falsas e material de ódio nas redes sociais, um levantamento divulgou que em 2018 essa prática piorou nos Estados Unidos, levando ao desenvolvimento das "junk news", traduzido como "notícias lixo" que além de falsas incluíam teorias da conspiração e material ofensivo. O estudo avaliou com nota de 0 a 100, sendo 0, nenhuma interação e 100, total interação com o junk news.

Os perfis de extrema direita tiveram notas acima de 89 , direita tradicional 83 , enquanto as páginas progressistas receberam notas abaixo de 46 e a esquerda institucional nota 24 (BENEVIDES, 2018). Fake News e Junk News (com o fomento de algumas figuras como Olavo de Carvalho) foram incorporadas na eleição de Bolsonaro aproveitando toda constante construção de uma mudança de mentalidade, convencendo as pessoas que o culpado era unicamente o Partido dos Trabalhadores, apresentando-se neste quadro como "salvador" do Brasil, uma pessoa "do povo" que vinha "acabar com a mamata".

\footnotetext{
${ }^{5}$ As notícias falsas, o termo em inglês popularizou-se e continuou a ser utilizado em língua inglesa.
} 
O impeachment causou uma ruptura na democracia e na estabilidade institucional, fazendo acelerar a decomposição política, enquanto o "cluster" central cooptou adeptos e aproveitou a situação de constante ataque ao PT, em boa parte fomentada por outros partidos golpistas como o PMDB, o Partido da Social Democracia Brasileira (PSDB) e pela mídia golpista. Em 2015 a direita mobiliza as pessoas nas ruas em protestos pró-impeachment, com foco no discurso da corrupção petista, embora os grupos fossem heterogêneos a identidade que os unia era o forte sentimento anti petismo (SOLANO, 2018).

O movimento Vem pra Rua, também foi um importante agregador dos grupos conservadores que viam em sua maioria os partidos como corruptos. Para Solano (2018) a justiça com formato de espetáculo promovida pela Operação Lava Jato, julgamentos televisados, a teatralização da justiça com conduções coercitivas sem nenhuma necessidade, foram fatores do convencimento da opinião pública, dentro do contexto de pós-golpe e ascensão de Jair Bolsonaro.

O político, que é percebido pela opinião pública como corrupto, passa por um processo de demonização. O político corrupto representa o "mal" e o juiz o "bem", numa visão dualista e pseudo-religiosa da realidade. 0 corrupto, portanto, não representa mais um sujeito de direito ao qual deve ser aplicado o devido processo penal respeitando direitos e garantias. 0 "mal" tem de ser extirpado, aniquilado e, para isso, o devido processo penal incomoda (SOLANO, 2018, p.5).

Soma-se a esse cenário a crise da representação partidária, mais presente nos partidos de esquerda tradicional que não acompanharam, nem compactuaram com esse nível de discurso. A vitória de Jair Bolsonaro demonstrou a vulnerabilidade da democracia, exposta ao autoritarismo e populismo da extrema direita. A população que se encontrava sem resposta do Estado, absorvem e compactuam dessa nova identidade, reforça-se a necropolítica neoliberal, colocando a violência contra pobres na periferia como algo normal, ou que não existe, criando uma relação entre democracia e violência.

No caso do Rio de Janeiro algumas pessoas até justificavam atos de total atrocidade, quando algum policial quase que diariamente matava um inocente, as pessoas tratavam logo de criar junk news, alegando que quem morreu era bandido 6 . Bolsonaro ganha força no pós impeachment, aproveita-se desse cenário e angaria ainda mais votos mesmo que filiado ao PSL e possuindo pouco tempo de televisão, descobre que sua campanha seria na rede social e no whatsapp.

Bolsonaro também descobre que não precisaria ir mais aos debates na televisão, pois ali ele expunha sua incapacidade diante da pergunta de outros candidatos. 0 candidato de extrema direita absteve-se com laudo médico (devido a facada que havia recebido na barriga), porém conseguia ir a programas de auditório de emissoras pretensamente seguras, que pertenciam a bispos que apoiavam sua candidatura. A prática de desaparecimento dos debates já havia sido usada por Crivella no Rio de Janeiro, que se negou a ir em vários

\footnotetext{
${ }^{6}$ Como o caso do estudante Bruno Silva de apenas 14 anos foi baleado pelas costas em um tiroteio na favela da Maré em 2018, apoiadores da política de morte inventaram mentiras de forma covarde, afim de justificar a morte e proteger a polícia criminosa.
} 
debates na televisão, ganhando mais tarde as eleições, pois não expôs nua inaptidão. Vale ressaltar que na disputa contra Crivella estava o Deputado Federal Marcelo Freixo (Partido Socialismo e Liberdade - PSOL), que também sofreu com as fake news, e o fantasma do "medo do comunismo".

Mesmo depois de um ano no cargo de Presidente o "território virtual" é um campo de grande organização da direita e do governo Bolsonaro. Com o tempo os grupos que fizeram parte da campanha se tornaram ainda mais extremos e radicais. Para Nemer (apud Betim, 2019), os extremistas estão divididos em três subgrupos:

1. Os "insurgentes": militaristas que consideram Bolsonaro pouco radical, identificados com 0 movimento fascista da década de 1930, os quais vem ganhando mais espaço na internet;

2. O núcleo de propaganda que é formado por bolsonaristas ${ }^{7}$ que apoiam e defendem a presidência a qualquer custo;

3. Os "supremacistas sociais", ligado aos evangélicos, tão radicais quando os insurgentes, cuja atuação nas redes sociais se dá pelo compartilhamento de conteúdo nazista, racista, anti-LGBT, anti-Nordeste.

Observa-se que a divisão em três grupos está ligado aos três clusters que antes foram agregados. Os três antigos clusters das redes sociais e os três subgrupos de extrema direita têm pontos em comum, mas também são conflitantes. Sublinha-se que Bolsonaro não conseguiu mantê-los unido por muito tempo, somente o bastante para ganhar a eleição. Considera-se também que esses grupos não são mais os mesmos clusters de antes, pois suas dinâmicas modificaram-se, nada é estático.

\section{RESISTIR É PRECISO}

Movimentos contrários à lógica neoliberal surgem e manifestam-se em diferentes espaços, reivindicando o direito à cidade.

Apenas grupos, classes ou frações de classes sociais capazes de iniciativas revolucionárias podem se encarregar das, e levar até sua plena realização, soluções para os problemas urbanos; com essas forças sociais e políticas, a cidade renovada se tornará a obra. Trata-se inicialmente de desfazer as estratégias e as ideologias dominantes na sociedade atual (HARVEY, 2014, p.113).

Cada movimento social é também um grupo de resistência e revolucionário, pois busca impedir e modificar o projeto vigente da elite. Porém, isso só é possível com ajuda do povo (da classe operária), caso

\footnotetext{
${ }^{7}$ Termo utilizado para identificar aqueles que apoiam o governo de Jair Bolsonaro.
} 
contrário, nenhum ato de resistência é possível. Logo, se torna essencial agregar mais pessoas às lutas políticas.

Resistir é preciso mesmo diante do controle da comunicação, outros meios podem ser criados. No século XXI a comunicação online passou a ser um espaço fundamental na dinâmica dos novos protestos políticos. Celulares conectados com transmissões ao vivo, ciberativismo, embates online e perfis bloqueados (GOHN, 2013). Essas novas formas visam superar barreiras impostas pelo Estado, uma vez que pelo meio online, manifestantes se organizam, mobilizam e recrutam (CASTELLS, 2013). Assim se organizam para atuar no espaço não virtual. Arte e conhecimento são manifestações particulares dessas necessidades (LEFEBVRE, 2001). Protestos foram organizados pelo Facebook em 2013, ativistas utilizavam grupos ou eventos da plataforma e posteriormente foram migrando para os grupos de Whatsapp. Considero que esses meios foram fundamentais para a organização dos protestos, ganharam mais espaço no decorrer dos anos.

Diversas são as concepções de espaço, uma delas de Lefebvre (apud Machado, 2017), divide em espaço isotópico, heterotópicos e utópicos. O espaço isotópico tem estreita relação com o neoliberalismo, sendo mercantilizados completamente; os espaços heterotópicos, são desmercantilizados, relacionados a apropriações e diversas utilizações do espaço e por fim os espaços utópicos são os lugares que não existem, um horizonte que desejamos e pretendemos alcançar, a isso nos leva ao debate sobre o direito à cidade pelo cidadão (MACHADO, 2017). O direito à cidade nos faz refletir sobre a imposição do Estado e sua atuação em conjunto com o projeto neoliberal, impedindo a ocupação dos espaços na cidade para outras práticas, alheias a mercantilização ${ }^{8}$. Para Flores (2009) o espaço pode ser três níveis de potência: a potência ontológica, sociológica e ética. A primeira, potência ontológica, é compreendida como "a luta contra todas as possíveis formas de esquecimento que visibilizam as experiências de rebeldia e de construção de alternativas ao longo da história" (p.191).

Silenciar a história e fazer esquecer são mecanismos de manipulação da memória coletiva, são instrumentos de poder, pois através da memória se faz recordar a tradição que aqueles que estão no poder permitam (LEGOFF, 1996). A potência sociológica, refere-se a pluralidade e multiplicidade das formas de vida, compreendendo-se que não existe uniformidade, todos somos diferentes e estamos em constante troca. Tal bandeira foi o discurso do liberalismo desde a sua origem, porém já demonstrou suas falhas e seletividade (BOBBIO, 1998; 2000; REMÓND, 1997).

A última, potência ética, "A potência de experimentar, de inventar hipóteses e novas formas de relação social" (FLORES, 2009, p.192). Isso é o que buscamos nos debates, reflexões e críticas. Essa potência só é possível em uma democracia, regimes totalitários e a necropolítica neoliberal não apreciam a reflexão e a informação como benéfica para seu projeto de cidade. $O$ atual governo de Jair Bolsonaro, dentre

\footnotetext{
${ }^{8}$ Ou até mesmo a mercantilização pelos ambulantes, camada mais pobre de trabalho autônomo ou o pequeno comerciante local.
} 
os vários exemplos já citados, indica constantemente cortes em cursos de humanas que visam a reflexão, ou nas palavras do governo, corte "principalmente em filosofia e sociologia" (CERIONI, 2019). Constantemente o governo pratica o negacionismo ${ }^{9}$, ataca professores de história, geografia, ciências sociais e incentiva que alunos desrespeitem professores e gravem aulas sem permissão. Esse governo destrói a educação de várias formas, pois busca acabar com toda forma de pensamento crítico e impor um pensamento único.

O espaço que se deseja cria são espaços de luta pela defesa dos direitos humanos, cobrando a realização efetiva e extensível a todos, essa será a nossa forma de construir a dignidade diante de um estado que visa o lucro e a morte. Portanto para Flores (2009) é necessário ocupar os espaços legais esquecidos pelo liberalismo político, transformando-os com culturas críticas e potencializando o protagonismo popular. Nesse contexto, por exemplo, foi o Festival de Fanfarras Ativistas, o Honk, realizado em agosto de 2015 na Praça da Harmônia que passava por reformas urbanas direcionadas a transformação do espaço para mercantilização de eventos futuros. O lugar foi escolhido para confrontar o projeto de cidade que o Estado pretendia, os músicos ativistas demonstraram como fazer arte gratuita. Também foi possível observa que:

Durante o festival Honk Rio - Festival de Fanfarras ativistas originário de Boston realizado entre os dias 6 e 9 de agosto de 2015 em diversas praças no centro do Rio de Janeiro, houve comentários de que policiais à paisana observavam a aglomeração a fim de saber se o festival e suas fanfarras de ativismo musical poderiam oferecer alguma ameaça à ordem local (MARTINS, 2015, p.198).

Esse festival foi realizado através de financiamento coletivo, onde todos ajudaram com uma quantia em dinheiro e esse valor foi utilizado para custear os gastos de locomoção e estadia de músicos que haviam vindo de fora do Brasil. Esse seria um exemplo de atuação social, que oferece música não mercantilizada a todos, demonstra-se assim que existem alternativas que não seja a mercantilização neoliberal. A ocupação das praças, parques, da escadaria da Câmara dos vereadores no Rio de Janeiro demarcam locais estratégicos simbólicos. São movimentos reativos (à crise econômica, antiglobalização, antineoliberalismo) e criativos, pois experimentam o espaço e o praticam. (GOHN, 2013; CERTEAU, 1994).

Utilizar a arte como expressão política não é algo novo, nos séculos XVIII e XIX, na Europa, já se recorria às marchas para protestar, fazendo uso também das músicas e palavras de ordem, formas básicas de comunicação, pois a maioria da população era analfabeta. Nas marchas e passeatas, havia a figura dos "repetidores", homens que ficavam em altos postes gritando palavras de ordem, repetindo o discurso das lideranças etc. Essa estratégia possibilitava que o grito das massas ecoasse conjuntamente, pois as pessoas repetiam; ou que os manifestantes em silêncio, ouvissem o conteúdo dos discursos (GOHN, 2013). Como aconteceu na Primavera dos Povos na Europa em 1848 na qual houve insurreições campesinas na qual marcharam com bandeiras e tambores para repartir as grandes propriedades, como destacou Hobsbawm

\footnotetext{
${ }^{9}$ Ato de negar a história ou dados científicos sem nenhuma base ou argumento
} 
(2014), a grande rebelião de 1525 a favor de Lutero em que camponeses atacaram os senhores rurais e príncipes, fazendo canções que criticavam o imperador; nos Países Baixos, quando canções eram acompanhadas de panfletos, gravuras e emblemas; na Alemanha em 1579 multidões atacavam a casa dos ricos cantando: Papen blot, ryckemans goet (sangue do papa, bens do rico), esses pressionavam a imediata reforma calvinista (BURKE, 2010).

A dinâmica no uso do espaço urbano pelos protestos organiza-se muitas vezes no calor do momento, no "improviso". Existem convenções, comportamentos e tradições de protesto, mas nenhuma manifestação será igual à outra. Em alguns casos a praça não é somente local de acolhimento do protesto - ela é o fato político que impulsiona os protestos (GOHN, 2013). Durante os atos contra os megaeventos e reivindicações de melhora na saúde e educação, em São Paulo foi realizado diversos protestos na Avenida Paulista, em frente o prédio da Fiesp ou no vão do Masp. No contexto paulista, esses locais foram escolhidos pelos manifestantes, pois eram localidades próximas, podiam dar visibilidade (performance) e possui forte simbolismo: era o novo centro de negócios, um dos centros financeiros da cidade pensada na lógica neoliberal desde a década de 1990, acabou sendo ocupado pela primeira vez com protestos políticos (SILVA, 2015).

O direito à cidade não é um simples retorno a uma cidade tradicional, mas sim um direito a vida urbana modificada do que temos hoje. E o tipo de cidade que habitamos e desejamos é inseparável do tipo de pessoa que desejamos nos tornar. Uma cidade alienada, baseada apenas nas relações comerciais, onde a vida é medida pelo que se tem no bolso e o consumismo desenfreado que busca satisfazer os ganhos pessoais mais cedo ou mais tarde trará raiva e frustração, teremos então uma população doente e dominada mentalmente.

É um processo lento e gradativo, um planejamento perverso que visa apenas o lucro de uma minoria. Seremos cidades fragmentadas e conflituosas geradas pela globalização guinada pelo neoliberalismo, ruidosa e movimentada, "organizada" em um caos mais ou menos controlado. Diferenças levam a segregação, marginalidade e exclusão e se não concordamos com esse tipo de cidade é por meio da mobilização e da luta social que devemos impedir o avanço de um projeto neoliberal. 0 Estado estará pronto a impor o medo, mas não devemos nos estagnar, pois são nossas ações diárias que fazem a cidade, como se fossemos arquitetos dos nossos futuros urbanos (HARVEY, 2013). Devemos continuar formando grupos de pressão.

O direito à cidade é um produto coletivo e de solidariedade social, a busca pela descentralização do neoliberalismo, dessa forma abrindo espaços para iniciativas locais que devem-se pensar viáveis a mercantilização imposta anteriormente (HARVEY, 2013). Esses espaços urbanos buscam a participação democrática, desfazendo a onda privatizante para criarmos uma cidade mais inclusiva, mesmo que ainda fracionada, baseado em demandas sociais e não excessivamente jurídico como o Estado liberal se comporta 
(CARDOSO, 2009). É o direito de fazer a cidade diferente e definir maneiras alternativas, o direito à cidade é um grito:

No espaço público - nas esquinas ou nos parques, nas ruas durante as revoltas e comícios - as organizações políticas podem representar a si mesmas para uma população maior e, através dessa representação, imprimir alguma força a seus gritos e demandas. Ao reclamar o espaço em público, ao criar espaços públicos, os próprios grupos sociais tornam-se públicos (MITCHELL apud HARVEY, 2013).

Harvey (2014) aponta alguns problemas que deveriam ser combatidos em nossa sociedade como a acumulação global de riqueza, a mudança no estilo de vida, incluindo o combate ao consumismo e a compreensão histórica e teórica da trajetória do desenvolvimento capitalista. Somente os trabalhadores poderiam estrangular o sistema, tal como os trabalhadores do setor de transportes seriam armas políticas extremamente eficazes. Cortar as linhas de produção, o alicerce que alimenta as cidades capitalistas. Não só o fornecimento de alimento e matéria-prima, mas também serviços básicos essenciais a vida urbana, como foi o caso da greve dos Garis no Rio de Janeiro em 2014 que conseguiu chegar a um acordo de mais de $37 \%$ de aumento (BARREIRA e ELIZARDO, 2014), apenas deixando o lixo acumular.

Porém esses são os formatos das lutas tradicionais, estamos diante de novos recursos que devem ser considerados e chegamos ao problema geral, como conscientizar a todos? Como libertar pessoas desse controle mental nas comunidades, subúrbios e favelas, pois nesses lugares falta 0 debate político, falta saneamento, educação, políticas públicas, portanto quem preenche isso são as igrejas (o político pastor) e 0 poder paralelo (milícias).

Como podemos falar com a classe oprimida que não consegue estudar, refletir e ter acesso à informação? Essas pessoas vivem suas dinâmicas locais, mesmo em um mundo globalizado, o que pesa pra eles é o preço da carne, da cesta básica, acesso a saúde e infraestrutura. A resposta para isso ainda está na ocupação do espaço. Vejamos o exemplo da atuação da milícia na Zona Oeste do Rio de Janeiro: por volta de 2005 o vereador Jerônimo Guimarães Filho, o Jerominho chefiava a milícia na zona oeste do Rio (Campo Grande), o seu poder paralelo ocupava os espaços que o Estado não ocupava, diante da demanda por mais saúde ele construiu um posto de saúde para atender a população local, espaço que era utilizado para campanha política.

A milícia e a igreja ocupam os espaços que o Estado faz questão de esquecer e são esses espaços que também devemos ocupar, não de forma física, mas de forma reflexiva e didática. Disputar esse espaço com a milícia e a igreja é extremamente complexo, pois envolve embate contra uma estrutura social já fixada e contra um poder paralelo criminoso. Mas tentar mudar as mentalidades e trabalhar aos poucos é necessário, a resposta para isso é "muito dialogo", a luta precisa ser didática.

Assim como Burke (2010) observa a cultura popular em toda idade moderna, também é possível observar que tais práticas dão continuidade na contemporaneidade, pois existem períodos na história do 
ocidente em que os cidadãos se interessam mais pela política, assuntos referentes ao Estado e suas práticas invadem a vida das pessoas e dessa forma a informação política passa a circular de forma mais intensa. Observa-se que o aparato repressor também se modifica se torna mais feroz e mortal, práticas da necropolítica.

Gostaria de refletir sobre a educação política no século XVIII na Europa em que Burke (2010) diz:

A educação política do povo comum foi uma educação informal pelos acontecimentos, e assim foi necessariamente intermitente; por exemplo, a geração de franceses que atravessou as guerras religiosas foi obrigada a ser politicamente consciente de uma maneira diferente da dos seus filhos e netos. No entanto, a centralização dos Estados e 0 crescimento dos exércitos (tendências que eram mais constantes do que intermitentes) significam que a política estava afetando a vida das pessoas comuns de modo mais direto e mais visível do que antes. [...] Os governantes impuseram taxações mais pesadas aos seus súditos para pagar esses exércitos e empregaram mais funcionários, em parte para coletar novos impostos. Os artesãos e os camponeses tinham boas razões para estar mais conscientes sobre o Estado no final do século XVIII do que trezentos anos antes (p.354355).

No Brasil do século XXI houve acúmulos de abusos, e um deles foi o constante aumento da passagem do transporte público. Até então sempre existiu "vida política", pessoas que eram interessadas e envolvidas iam às ruas protestarem. Porém, 2013 foi um estopim e grandes manifestações estavam acontecendo pelo mundo, pouco antes e depois de levar muitas pessoas às ruas, nos anos seguintes cada grupo foi encontrando o seu lugar: manifestações sindicais, de jovens estudantes, das esquerdas ou verdes amarelas de direita. Felizmente ou infelizmente essa foi a educação política forçada da maioria dos brasileiros a partir de então. Nesse contexto é que a extrema direita cresce junto a burguesia neoliberal, sabe como aproveitar melhor a situação, não é a toa que o resultado final disso é um presidente fascista, de extrema direita com um plano de governo neoliberal representado por Paulo Guedes, esse seria o casamento perfeito.

\section{O QUE FAZER ENTÃO? CONSIDERAÇÕES FINAIS}

O contexto histórico da disputa pelo espaço mundial neoliberal se liga as transformações no Brasil, um país globalizado do cenário capitalista. A porta de entrada definitiva inicia-se na ditadura militar, que fazia partes das ditaduras latinas-americanas financiadas pelos Estados Unidos, o país que comandava a política capitalista por todo o mundo e na qual a burguesia neoliberal surfava, aproveita-se um mecanismo imperialista que duravam décadas, implantando algumas inovações comerciais. Essa "onda" globalizante da economia se desenvolveu pela década de 1990 enquanto o neoliberalismo já demonstrava seus efeitos nocivos à sociedade, expandindo-se para a vida privada e o espaço ocupado. Tudo é ação e reação, grupos contrários de resistência surgiriam o que fariam por sua vez, os grupos opressores também modificarem-se em busca de maior e melhor eficiência na busca pelo poder. 
A necropolítica se instaura como ato cirúrgico na ditadura militar durante a década de 1960 e 1970, "adormece", durante o período de internacionalização financeira indireta e nos anos seguintes, na década de 1980, quando se inicia a liberalização financeira fazendo ressurgir a burguesia neoliberal, nesse contexto a necropolítica apresenta-se no Estado Moderno durante os sucessivos golpes na América Latina no século XXI. Diante da crise subprime de 2008, ações são tomadas pelo governo petista e em 2009 faz-se cumprir as promessas de Lula, o tsunami havia virado uma marola, talvez um pouco mais forte do que previa, mas assegurou a economia com margem de sucesso. A burguesia neoliberal queria mais que isso, visava 0 Estado mínimo e o poder, portanto, mesmo que o PT favorecesse setores liberais em seu governo, ainda não cumpria com totalidade a agenda neoliberal com a total privatização das estatais.

Os anos seguintes colocariam a cidade do Rio de Janeiro na mira dos megaeventos, preparar e maquiar a cidade para o mercado internacional, desvirtuando o uso do espaço público e visando o lucro dentro da lógica neoliberal seria essencial para a transformação da cidade do Rio de Janeiro e preparação para a chegada das burguesias neoliberais. A transformação da cidade se daria ainda no governo petista, acentuando-se a prefeitura de Eduardo Paes e seria ainda mais exacerbado depois do golpe, piorando ainda mais seu cenário com o a prefeitura de Marcelo Crivella e governo de Wilson Witzel. A atuação no espaço público, contra as dinâmicas culturais e o comércio informal seriam agressivas, violentas e criminosas.

Buscou-se convencer a opinião pública, que reprimir camelôs, manifestações culturais e protestos de rua era o melhor a se fazer. A prefeitura de Eduardo Paes apontou para problemas reais da cidade, mas buscou enfrentá-lo numa lógica de guerra, investindo em aparato policial e não em diálogo. Práticas da necropolitica acordavam com fome, ganhando ainda mais coragem no governo de Witzel, fortalecido pela política de Bolsonaro.

Mesmo diante de tamanhas atrocidades pelos governantes a cidade ainda seria adequada e maquiada para o consumo internacional, foram feitos todos preparativos da cidade para os sucessivos eventos esportivos, o "urbanismo olímpico", agredindo mais uma vez a dinâmica dos espaços e suas vivências. Essa agressão espacial levou a mais invisibilidade da pobreza, não soluciona os problemas sociais, os megaeventos ficaram acima das pessoas.

Quem vive na pobreza sofre com a força opressiva do Estado, enquanto aqueles que vivem em zonas mais abastadas alienam-se dessa realidade, a propaganda é tão forte que até mesmo o pobre e excluído, também concorda com a visão silenciadora. A mídia e a propaganda induzem a passividade. Investe-se no aparato policial para melhor oprimir, a população concorda que esse é o melhor e único caminho. Alguns vão reagir, resistir e novamente o Estado vai buscar novas formas de opressão e silenciamento. Banaliza-se a violência e a vida, a população também se torna mais apática e violenta diante dessa normalização, vivemos então em uma sociedade cada vez mais doente, uma sociedade neoliberal. 
O governo da necropolitica neoliberal manipula a educação, para assim moldar cidadãos em harmonia com seus ideais. Nesse aspecto não só a escola pública é sucateada como o conteúdo que deve ser veiculado, os pais já doutrinados ajudam na vigilância do conteúdo, portanto cria-se uma educação que prepare os jovens para a sociedade neoliberal. Porém o projeto de construção do inimigo, precisa ser um pouco mais rápido que doutrinar uma geração de berço, é nesse momento que a mídia faz o seu papel de manipular a informação. Dessa forma a Rede Globo criou uma visão exagerada e pervertida da crise utilizando uma antiga fórmula: criar um inimigo para ser combatido, praticamente transplantamos os anos de guerra fria para o século XXI.

A apropriação foi constante pela direita brasileira, começaram a tomar espaço ainda em 2013, aproveitando-se dos protestos de rua, alguns realizados por movimentos de esquerda que pediam fim do ajuste fiscal no governo Dilma (2015). A direita ganhou espaço, fizeram seu próprio protesto na praia de Copacabana ao domingo, apropriaram-se das cores nacionais. O espaço foi utilizado de diferentes maneiras, protestos de esquerda visavam dias de semana, em diversas partes do centro urbano e os protestos de direita as praias, zona nobre da cidade aos domingos. A esquerda escolhia seus espaços com base em outra lógica, uma estratégia que visava chamar a atenção das autoridades, parar o trânsito, protestar, ocupar espaços simbólicos, a direita visava um "protesto show", clima perfeito para a mídia fazer a sua parte. A mídia extrapolou toda e qualquer percepção da crise, fez o seu papel diante do golpe que estava em andamento, a história se lembrará.

É notável que após 2013, muita gente passou a se interessar por política, porém muitas ainda serviam como massa de manobra. Pessoas descobrem que podem e devem fazer parte do jogo político, mas não aprofundam o conhecimento no assunto, passando a conceber o jogo político tal como um jogo de futebol, uma disputa binária entre o bem e o mal, entre o meu e o seu. Acreditou-se em fake news, junk news, em promessas, mentiras e senso comum. Os antigos resquícios de ditadura que condenaram toda uma geração nascida na década de 1980 e 1990, fadados a generalizar a cultura da "política, futebol e religião não se discute", foram ensinados que política era coisa de gente chata ou de ladrão corrupto.

Melhor era praguejar contra o que não se conheciam e por mais de três décadas a alienação política imperou em boa parte dos brasileiros, mas 2013 marcou, pois foi quando o brasileiro notou que poderia ser um sujeito político, é nesse momento que o projeto neoliberal compreende que precisa agir rápido influenciando a opinião pública também, e nessa dança até mesmo a igreja (com destaque para a evangélica) percebeu que o jogo político valia a pena. Muita gente que se reconheceu sujeito político, rapidamente foi direcionada por falsos gurus, o gado já havia sido manobrado. Felizmente os mais novos, a geração do século XXI estava mais questionadora, crítica e vivenciando também pela primeira vez a disputa política nas ruas, observando os movimentos de resistência, os embates e ouvindo a voz das minorias. 
Os jovens dessa geração teriam contato com um conteúdo rico da política ainda em sua primeira década de vida. Difere daquela geração dos anos de 1980 ou 90, aqueles condenados pela herança da ditadura militar, que possuíam opinião formada e muito menos abertos a aprender algo novo, de pessoas mais velhas que precisavam desconstruir suas certezas antes de compreender as incertezas. Os jovens foram em grande parte a força motriz dos protestos de rua no Rio de Janeiro. Não foram jovens desmiolados, revoltosos de classe média, anarquistas inúteis que gastavam suas energias como disse Arnaldo Jabor, esses estão em momentos históricos que construíram seu caráter político de forma positiva, são também uma forma de resistência e merecem total apoio.

Não é possível dizer que a televisão e outras mídias tiveram total sucesso na manipulação das informações, porém ajudaram bastante, principalmente no primeiro momento do golpe. Com o passar do tempo o Jornal Nacional da Rede Globo, por exemplo, passou a ser odiado tanto por vertentes de esquerda como de direita, os primeiros por toda a ajuda ao golpe, e os segundos por uma suposta "esquerdização" do jornal e da emissora. A televisão tentou jogar dos dois lados, hora fazendo o jogo político de um, hora tentando combater Jair Bolsonaro e o fantasma fascista que ele trazia consigo, era tarde demais.

Entregues e diante da nova realidade presidencial, tentaram mais uma vez jogar a favor, com William Bonner batendo continência dando boas-vindas ao atual Presidente. As pessoas expostas ao markting da cidade também estavam propensas a ouvir e acreditar algum discurso na qual se identificassem. Discursos que fossem fáceis de serem assimilados, porque a realidade é mais complexa e as vezes mais chata. Cria-se condições de alienação com a constante redução do tempo livre, como dizia Thompson (1987). Práticas estrangeiras de propagação das notícias falsas, conspiratórias foram absorvidas e Bolsonaro aproveitou 0 momento ${ }^{10}$, pois a mentalidade já havia sido trabalhada por outros grupos de direita. 0 Impeachment de

Dilma deteriorou a democracia, em cima disso os "abutres" fizeram a festa, criaram o cenário que gostariam, estimularam e manipularam as mentalidades. Dentro do contexto o candidato com discurso de ódio, como Bolsonaro, ganha espaço explorando medos mais profundos da população, prometendo fórmulas milagrosas, ganha quem sabe falar a língua do povo de seus problemas mais emergentes. Parte dessa noção de violência também é culpa da mídia, pois somos bombardeados a anos com programas polícias e violência gratuita na televisão. Diante desse cenário também não é espantoso notar ondas de linchamentos pelas ruas aos supostos criminosos, como ocorridos em 2013 e 2014.

É possível o uso do espaço coletivo não mercantilizado, porém para que isso possa acontecer é necessário respeitar e ouvir as dinâmicas locais e já que o Estado não tem esse respeito, devemos nós moradores ocuparmos e fazermos as dinâmicas acontecerem nós mesmos, pois a participação democrática

\footnotetext{
${ }^{10}$ Não inclui o evento da facada que Jair Bolsonaro recebeu na barriga em uma comitiva eleitoral, pois considero muito complicado e extenso analisar o evento, porém considero que ele deu uma ajuda naqueles que já estavam tendendo a apoiar o candidato.
} 
não está apenas nas eleições, mas sim no dia a dia, na forma como queremos viver nossas vidas. Observo que a arte tem grande potencial nas ocupações, uma das melhores formas de expressão nessas ocasiões.

Devemos buscar o nosso direito à cidade, e essa busca será sempre coletiva. Algumas situações parecem impossíveis, como os espaços ocupados pelo poder paralelo, porém devemos ser didáticos, qualquer pequena mudança de resistência que seja possível fazer é algo que pode ajudar a mudar no futuro. Uma aula, uma conversa, um evento didático, debates etc. Pequenos movimentos podem tornar-se gigantes no futuro e precisamos ter consciência que talvez não estejamos construindo algo para nós, pois as mudanças são lentas e gradativas e desconstruir estruturas requer tempo.

Todos aqueles cujo trabalho está envolvido em produzir e reproduzir a cidade têm um direito coletivo não apenas àquilo que produzem, mas também de decidir que tipo de urbanismo deve ser produzido, onde e como (HARVEY, 2014). Parte de nossa capacidade de criar, recriar e transformar o meio em que vivemos e na qual podemos intervir, o direito à cidade é um direito coletivo. Ocupar as ruas em protesto é uma forma de modificar esse espaço, é um corpo político coletivo e por isso o poder político busca reestruturar a infraestrutura urbana e incutir o medo, pois sabe que é um importante espaço estratégico de atuação. № meio urbano, a vista de todos, a opinião pública pode ser mudada e isso é perigoso para quem detêm o poder. Portanto atuar onde quer que seja é tão ou mais importante que a manifestação de rua.

Esse processo ético e educativo, para evitar imposições ideológicas "desde cima", requer uma concepção ampla e não fragmentada da ação. Desse modo, superamos todo tipo de falácia naturalista, pois somente a partir da concepção que conecta o conhecimento do real (o que é) com as propostas alternativas de outra forma de relação social (o que deve ser) evitaremos que apenas as elites decidam nosso presente e nosso futuro. Dessas referidas posturas elitistas é muito fácil sustentar que os seres humanos não têm formação para participar e decidir em política. Segunda essa tese, cada tipo de ação será definida por suas próprias caraterísticas, e ninguém poderá passar do que é sua realidade (o "é") a uma crítica da mesma (o "deve ser"). Chegaremos com isso ao "gorila amestrado" que consome e vive sua vida privada à margem do político (FLORES, 2009, p. 193).

Pensemos que a luta é pela defesa e abrangência dos direitos, a fim de combater o projeto neoliberal e a normalização da necropolítica. A luta para difundir, conscientizar e mudar as percepções. Um trabalho árduo, pois, em era da informática e tantos influenciadores digitais que propagam falácias e desconhecimento a tarefa parece cada dia maior e não dar resultados. Porém nossa percepção pode nos enganar. Chomsky (2013), diz que em alguns casos os manifestantes podem não vencer, mas o ato da manifestação em si é importante e não devemos perder as esperanças, pois "Se as pessoas se conformarem em estar desamparadas, isoladas, atomizadas, o poder hegemônico vai vencer. Estas questões são muito graves. Neste exato momento, por exemplo, pela primeira vez na história humana, estamos realmente diante da perspectiva da destruição da espécie" (Chomsky, 2013, p.45). 
Gostaria de frisar o que disse no início desse artigo, que em vários momentos históricos e diferentes contextos, demonstram que estamos em constante embate de interesses contra a elite que visa um tipo de cidade, impondo valores e uma forma de pensamento único.

Somente nossa relação de resistência pode mudar essa realidade, muitos vão se machucar, fracassar, morrer, mas a ação de cada um vai impedir que algo pior aconteça, o cenário é desolador. Porém frutos podem ser colhidos, em certos contextos podemos comemorar uma vitória. Compreendo que a frase de Chomsky, apresentada nesse último parágrafo, reflete a nossa destruição, passivos diante da vida miserável que pode nos ser dada se não resistirmos e dermos trabalho para eles. Portanto, para nossa sobrevivência, ocupar e resistir se faz necessário, é uma obrigação.

\section{REFERÊNCIAS}

AGÊNCIA SENADO. Decisão de cortar verbas para universidades repercute no Senado. 2019. Disponível em

$<$ https://www12.senado.leg.br/noticias/materias/2 019/04/30/decisao-de-cortar-verbas-parauniversidades-repercute-no-senado $>$ Acesso em: 5 de janeiro de 2020.

BARAN, Katna. Ex-presidente Lula é solto após 580 dias preso na Política Federal em Curitiba. 2019. Disponível em $<$ https://www1.folha.uol.com.br/poder/2019/11/ex -presidente-lula-e-solto-apos-580-dias-preso-napolicia-federal-em-curitiba.shtml > Acesso em: 6 de janeiro de 2020.

BARREIRA, Gabriel; ELIZARDO, Marcelo. "Vitória é do Rio", diz gari Sorriso sobre o fim da greve da categoria. Disponível em $<$ http://g1.globo.com/rio-dejaneiro/carnaval/2014/noticia/2014/03/vitoria-edo-rio-diz-gari-sorriso-sobre-fim-da-greve-dacategoria.html > Acesso em: 8 de agosto de 2019.

BARROS, José D`Assunção. O campo da história especialidades e abordagens. Petrópolis, RJ: Vozes, 2004.

BAUMAN, Zygmunt. A sociedade individualizada: vidas contadas e histórias vividas. Rio de Janeiro: Zahar, 2008.

BENEVIDES, Bruno. Uso de fake news nos EUA em 2018 já ultrapassa eleição de Trump, diz Oxford. 2018. Disponível em <https://www1.folha.uol.com.br/mundo/2018/11/u so-de-fake-news-nos-eua-em-2018-jaultrapassa-eleicao-de-trump-diz-oxford.shtml > Acesso em: 5 de janeiro de 2020.

BETIM, Felipe. Do bolsonarismo ao integralismo, como a extrema direita se organiza na internet. 2019. Disponível em $<$ https://brasil.elpais.com/brasil/2019-12-28/dobolsonarismo-ao-integralismo-como-a-extremadireita-se-organiza-nainternet.html?\%3Fssm=FB BR CM\&hootPostID $=5 \mathrm{~d} 746 \mathrm{f} 13 \mathrm{~b} 15 \mathrm{fc} 500 \mathrm{c} 369 \mathrm{ed} 3 \mathrm{cfd} 2 \mathrm{cc002 \& fbclid=I \textrm {w }}$ AR18IVKILt6Tg36Wcgwly9nyIDiBfMiURyAz5q7Z k5QmE5w7PtHFY2KzOd8 > Acesso em: 5 de janeiro de 2020.

BEZERRA, Arthur Coelho. Modernismo, tropicália e manguebeat: antropofagia musical brasileira em três atos. In: FERNANDES, Dmitri Cerboncini; SANDRONI, Carlos. Música e ciências sociais: para alémdo descompasso entre arte e ciência. 1.ed. Curitiba: Editora Prismas, 2016. p.221-242.

BITTENCOURT, Circe Maria. Ensino de história: fundamentos e métodos. 2 ed. São Paulo: Cortez, 2008.

BOBBIO, Norberto. Dicionário de política. Brasília: Editora Universidade de Brasilia, $11^{\text {a }}$ ed, 1998. Liberalismo e democracia. São paulo: Brasiliense, 2000.

BOITO JR. Armando. Os atores e o enredo da crise política. In: JINKINGS, Ivana; DORIA, Kim; CLETO, Murilo. Por que gritamos golpe?: para 
entender o impeachment e a crise. 1.ed. São

Paulo: Boitempo, 2016. p.23-30.

BURKE, Peter. Cultura popular na Idade Moderna:

Europa 1500-1800. São Paulo: Companhia das Letras, 2010.

CARAPANÃ. A nova direita e a normalização do nazismo e do fascismo. In: SOLANO, Esther. 0 ódio como política: a reinvenção das direitas no Brasil. Boitempo, 2018.

CARDOSO, Clodoaldo Meneguello. Liberdade e igualdade nos direitos humanos: fundamentos filosóficos e ideológicos. In: CARDOSO, Clodoaldo Meneguello. Educação em direitos humanos na formação universitária: textos para seminários. Bauru: UNESP/OEDH; FAAC; Cultura Acadêmica, 2009.

CASTELLS, Manuel. Redes de indignação e esperança: movimentos sociais na era da internet. Rio de Janeiro: Zahar, 2013. Brasil está entrando em uma ditadura sutil com Bolsonaro afirma Castells. 2019. Disponível em $<$ https://noticias.uol.com.br/ultimasnoticias/efe/2019/07/16/brasil-esta-entrando-emuma-ditadura-sutil-com-bolsonaro-afirmacastells.htm? > Acesso em: 8 de agosto de 2019. CERIONI, Clara. No Twitter, o presidente afirmou que os repasses serão destinados a projetos que ensinem os jovens "leitura, escrita e fazer conta". 2019. Disponível em $<$ https://exame.abril.com.br/brasil/bolsonarosugere-reduzir-verba-para-cursos-de-filosofia-esociologial > Acesso em: 5 de janeiro de 2020. CERTEAU, Michel. A invenção do Cotidiano: 1. Artes de fazer. Petrópolis, RJ: Vozes, 1994. CHOMSKY, Noam. Sistemas de poder. conversas sobre as revoltas democráticas globais e os novos desafios ao império americano-entrevistas com David Barsamian. 1.ed. Rio de Janeiro: Apicuri, 2013.

CLETO, Murilo. O triunfo da antipolítica. In: JINKINGS, Ivana; DORIA, Kim; CLETO, Murilo. Por que gritamos golpe?: para entender 0 impeachment e a crise. 1.ed. São Paulo: Boitempo, 2016, p.43-48.

CORREIO BRASILIENSE. Wilson Witzel comemora desfecho com morte do sequestrador no Rio de Janeiro. 2019. Disponível em $<$ https://www.correiobraziliense.com.br/app/notici a/brasil/2019/08/20/interna-brasil,778167/wilsonwitzel-comemora-desfecho-com-morte-do- sequestrador-no-rio-de-ja.shtml > Acesso em: 5 de janeiro de 2020.

COULANGEON, Phillipe. Sociologia das práticas culturais. São Paulo: Edições Sesc São Paulo, 2014.

FERNANDES, Florestan (cord.); RODRIGUES, José Albertino (Org.) Durkheim. São Paulo: Editora Ática, 1990.

FREITAS, Ricardo Ferreira; SANTOS, Maria Helena Carmo dos; LINS, Flávio. Porto Maravilha: construção da narrativa do branding urbano para a cidade olímpica 2016. In: HELAL, Ronaldo; GASTALDO, Édison. Copa do Mundo 2014: futebol, mídia e identidades nacionais. $1^{\text {a }}$ edição- Rio de Janeiro: Lamparina, Leme, 2017. p.148-162.

GALHARDO, Ricardo. Lula: crise é tsunami nos EUA e, se chegar ao Brasil, será 'marolinha'. 2008. Disponível em $<$ https://oglobo.globo.com/economia/lula-crisetsunami-nos-eua-se-chegar-ao-brasil-seramarolinha-3827410 > Acesso em: 5 de janeiro de 2020.

GEFAELL, Clara Valverde. De la necropolítica neoliberla a la empatía radical: Violencia discreta, cuerpos excluidos y repolitización. Barcelona: Icaria, Más Madera. 2015.

GOHN, Maria da Glória. Os jovens e as praças dos indignados: territórios de cidadania. In: Revista Brasileira de Sociologia. Sociedade Brasileira de Sociologia -SBS. - Vol, 1. n.2 (jul./dez.2013). Sergipe: SBS, 2013.

HARVEY, David. A liberdade da cidade. In: MARICATO, Ermínia et al. Cidades rebeldes: Passe Livre e as manifestações que tomaram as ruas do Brasil. 1. ed. São Paulo: Boitempo: Carta Maior, 2013. n.p.

Cidades rebeldes: do direito à cidade à revolução urbana. São Paulo: Martins Fontes selo Martins, 2014.

HERRERA FLORES, Joaquín. A reinvenção dos direitos humanos. Florianópolis: Fundação Boiteux, 2009.

HOBSBAWM, Eric J. Era dos Extremos: o breve século XX: 1914 - 1991. São Paulo: Companhia das Letras, 1995.

A era do capital, $1848-1875.21^{\mathrm{a}} \mathrm{ed}$. São paulo: Paz e Terra, 2014.

JUSTI, Adriana; DIONÍSIO, Bibiana. Japonês da Federal é preso em Curitiba por facilitar contrabando. 2016. Disponível em: 
<http://g1.globo.com/pr/parana/noticia/2016/06/ja pones-da-federal-e-preso-em-curitiba.html > Acesso em: 5 de janeiro de 2020.

LATOUR, Bruno. Reagregando o social. Salvador: Edufba, 2012; Bauru, São Paulo: Edusc, 2012.

LEFEBVRE, Henri. O direito à cidade. São Paulo: Centauro, 2001.

LEGOFF, Jacques. História e memória. 4.ed. Campinas, SP: Éditora da UNICAMP, 1996.

LIMA, Thais Damasceno; DEUS, Larissa Naves. A crise de 2008 e seus efeitos na economia brasileira. In: Revista Cadernos de Economoia, Chapecó, v.17, n.32, p.52-65, jan.jjun. 2013.

LÖWY, Michael. Da tratégia à farsa: o golpe de 2016 no Brasil. In: JINKINGS, Ivana; DORIA, Kim; CLETO, Murilo. Por que gritamos golpe?: para entender 0 impeachment e a crise. 1.ed. São Paulo: Boitempo, 2016. p.61-68.

MARTINS, Daniel. Música, identidade e ativismo: a música nos protestos de rua no Rio de Janeiro (20132015). In: GUAZINA, Laize. Dossiê Som e/ ou Música, Violência e Resistência. Revista Vórtex, v.3, n.2, 2015, p.188-207.

MENEGUELLO, Rachel; AMARAL, Oswaldo E. do; SIMONI JR. Sérgio. A Cara da Democracia no Brasil. Relatório N.1 de divulgação de pesquisa nacional realizada pelo Instituto Nacional de Ciência e Tecnologia (INCT) - Instituto da Democracia e da Democratização da Comunicação. Belo HorizonteBrasília-Campinas-Rio de Janeiro; Maio/2018 MIGUEL. Luis Felipe. A democracia na encruzilhada. IIn: JINKINGS, Ivana; DORIA, Kim; CLETO, Murilo. Por que gritamos golpe?: para entender 0 impeachment e a crise. 1.ed. São Paulo: Boitempo, 2016 . p.31-38.

A reemergência da direita brasileira. In: GALLEGO, Esther Solano. O ódio como política: a reinvenção das direitas no Brasil. Boitempo, 2018.

MBEMBE, Achille. A era do humanismo está terminando. 2016. Disponível em: <https://www.pensarcontemporaneo.com/humanismo -mbembe > Acesso em: 8 de agosto de 2019.

. Necropolítica. In: Arte \& Ensaios. Revista do ppgav/eba/ufrj, n.32, dezembro 2016.

MACHADO, Fernanda Amim Sampaio. Ei você aí, me dá um dinheiro aí?: conflitos, disputas e resistências na cidade do Rio de janeiro. Rio de Janeiro: Lumen Juris, 2017.

MORAES, Antonio Carlos Robert; COSTA, Wanderley Messias da. A valorização do espaço. São Paulo: EDITORA HUCITEC, 1984.

NITAHARA, Akemi. Sequestrador estava em surto psicótico e ameaçou incendiar o ônibus. 2019. Disponível em: <http://agenciabrasil.ebc.com.br/geral/noticia/201908/sequestrador-estava-em-surto-psicotico-e- ameacou-incendiar-0-onibus > Acesso em: 5 de janeiro de 2020.

PIRES, Lenin. Transportes públicos, cidadania e política: Grandes eventos e 'globalização'no Rio de Janeiro. In: Dilemas, Rev. Estud. Conflito Controle Soc, Rio de Janeiro, nº 3, 2019, p.11-28.

PREFEITURA DO RIO DE JANEIRO. Plano estratégico da Cidade do Rio de Janeiro - Pós 2016: o Rio mais integrado e competitivo. Rio de Janeiro, 2009.

QUIRINO, Flávia; GUAZINA, Liziane. Golpe no Brasil: o que a mídia tem a ver com isso? In: Revistas Estudos em Comunicação. № 26, vol.2, 2018, p.179-188.

RIBEIRO, Márcio Moretto. Antipetismo e conservadorismo no Facebook. In: GALLEGO, Esther Solano. $O$ ódio como política: a reinvenção das direitas no Brasil. Boitempo, 2018.

RIO. Choque de Ordem. 2009. Disponível em: <http://www.rio.ri.gov.br/web/guest/exibeconteudo?art icle-id=87137 > Acesso em: 8 de agosto de 2019.

RODRIGUES, Artur; LOBEL, Fabricio. Incêndio toma conta de favela na radial leste que seria desocupada. 2019. Disponível em:

<https://www1.folha.uol.com.br/cotidiano/2019/03/inc endio-toma-conta-de-favela-na-radial-leste-que-seriadesocupada.shtml > Acesso em: 8 de agosto de 2019.

RÉMOND, Réne. O Século XIX: 1815-1914. São Paulo: Cultriz, 1997.

SANTOS, Milton. Por uma outra globalização: do pensamento único à consciência universal. $25^{\mathrm{a}} \mathrm{ed}$. Rio de Janeiro: Record, 2015.

SILVA, Adriana Bernardes. 0 território brasileiro e a superposição da dinâmica globalizadora: círculos descendentes e ascendentes de informações. Por outra leitura de metrópole (contribuições ao debate). In: SILVA, Catia Antonia da; CAMPOS, Andrelino. Metrópoles e invisibilidades: da política às lutas de sentidos da apropriação urbana. $1^{a}$ edição. Rio de Janeiro: Lamparina, FAPERJ, 2014, p.36-44.

SOLANO, Esther. Crise da democracia e extremismos de direita. São Paulo: Friedrich-Ebert-Stiffung Brasil, No 42, 2018.

THOMPSON. E. P. A formação da classe operária inglesa II: A maldição de Adão. Rio de Janeiro: Paz e terra, 1987.

VAINER, Carlos B. Pátria, empresa e mercadoria: notas sobre a estratégia discursiva do planejamento estratégico urbano. In: ARANTES, Otília Beatriz Fiori; VAINER, Carlos B.; MARICATO, Emínia. A cidade do pensamento único: desmanchando consensos. 8.ed. Petrópolis: Vozes, 2013, p.75-104.

XAVIER, Marcos Antonio de Moraes. Modernização, expansão do consumo e pobreza urbana. In: SILVA, Catia Antonia da; CAMPOS, Andrelino. Metrópoles e invisibilidades: da política às lutas de sentidos da 
apropriação urbana. $1^{\text {a }}$ edição. Rio de Janeiro:

Lamparina, FAPERJ, 2014, p.27-35. 